\title{
Kravet som juridisk fiksjon
}

- Kommentarer til debatten om rettskraft og HR-2018-1130-A

\section{Av førsteamanuensis ph.d. Markus Jerk}

Med debatten om HR-2018-1130-A som bakteppe tar artikkelen opp sider av problemet om kravets identitet - spørsmålet om når to krav skal anses identiske etter rettskraftens avvisningsregel $\mathrm{i}$ tvisteloven § 19-15 (3). Forarbeidenes forståelse og rådende oppfatninger i teorien kritiseres. Kravbegrepets rolle i diskusjonen problematiseres. Et skille mellom ekstingverende, avledet, prekluderende og utvidet rettskraft, som kan bidra til en endelig løsning på problemet, introduseres.

Nøkkelord: erstatning, fiksjon, klarspråk, krav, litispendens, prisavslag, prosess, rettskraft

\section{Innledning}

Etter tvisteloven $\S 19-15$ tredje ledd skal retten «avvise en ny sak mellom samme parter om et krav som er rettskraftig avgjort, om ikke saksøkeren på grunn av tvist om avgjørelsens bindende virkning eller andre særlige forhold likevel har søksmålsinteresse etter $\S 1-3 »$. Dette reiser et spørsmål om hvordan grensene for hva som i prosessuell forstand utgjør det samme «krav», etter denne bestemmelsen, skal trekkes opp: a) Vil dom på betaling for et utført tjenesteoppdrag sperre for et senere krav om prisavslag fra kjøper? b) Skal et krav om prisavslag og et krav om erstatning anses som samme «krav»?

I HR-2018-1130-A svarte Høyesterett bekreftende på begge spørsmål. En kjøper av rørleggertjenester var ved rettskraftig fraværsdom i forliksrådet dømt til å betale to ubetalte fakturaer fra rørleggeren. Høyesterett bygget på forarbeidene ved besvarelsen av det første spørsmålet. Der var det lagt til grunn at et krav om prisavslag regnes som en innsigelse mot vederlagskravet, slik at det $\mathrm{i}$ utgangspunktet ikke kan fremmes som et selvstendig krav i en senere sak (avsnitt 25). Forarbeidene gav ikke tilsvarende støtte til svaret på det andre spørsmålet. Om dette var det uttrykt, med henvisning til flertallet i Rt. $2000 \mathrm{~s} .199$ Pelsdyrhall, at krav om prisavslag og erstatning ikke skal anses som samme «krav». Når Høyesterett likevel valgte å anse krav om prisavslag og erstatning som samme «krav», skyldtes det senere rettspraksis, som ifølge Høyesterett medførte at man kunne stille spørsmål ved rekkevidden av avgjørelsen i Pelsdyrhall, samt at rettsfølgene av prisavslag og erstatning som kontraktbruddsanksjoner er kvalitativt like, og at det var god prosess $\emptyset$ konomi å behandle disse kravene samlet (avsnitt 29-32).

I Lov og Rett nr. 8/2018 stiller $\varnothing$ rnulf $\varnothing$ yen kritiske spørsmål til Høyesteretts avgjørelse. ${ }^{1}$ Han argumenterer for at løsningen i kjennelsen er uheldig. Den reiser vanskelige avgrensningsspørsmål om hvilke innsigelser og motkrav som anses som en del av vederlagskravet. Dette vil igjen $\emptyset$ ke behovet for veiledning fra domstolene. Og det er tvilsomt om prosess $\varnothing$ konomiske hensyn kan veie opp for disse ulempene. ${ }^{2} \varnothing$ yen er også kritisk til Høyesteretts rettskildebruk i saken. Han innvender at retten kan ha trukket uriktige slutninger fra forarbeidene og for vidtrekkende slutninger fra

\footnotetext{
${ }^{1} \varnothing$ rnulf $\varnothing$ yen, «Hva utgjør det prosessuelle «kravet» i kontraktsrettslige tvister? - noen tanker om Høyesteretts avgjørelse i sak HR-2018-1130-A», Lov og Rett, 2018 s. 493-503. DOI: http://dx.doi.org/10.18261/issn.1504-3061-2018-08-04. Se ellers Maria Astrup Hjort, «Materielle og prosessuelle krav - en kommentar til Ørnulf Øyens artikkel om HR-2018-1130-A», Lov og Rett, 2018 s. 580-581. DOI: http://dx.doi.org/10.18261/issn.1504-3061-2018-09-05.

${ }^{2} \varnothing$ yen 2018, s. 500-501.
} 
tidligere rettspraksis. Dette ledet til at de reelle hensyn, og da særlig rettstekniske hensyn og hensynet til forutberegnelighet for partene, ikke ble tilstrekkelig analysert. ${ }^{3}$

Jeg er enig med $\varnothing$ yen i at avgjørelsen er uheldig. Den har etter mitt gehør noe umusikalsk ved seg, og bidrar til å skape disharmoni i rettssystemet. Jeg tror dette kommer tydeligere frem om man kritiserer dommen langs enklere linjer - i mer hverdagslige ordelag - enn hva Øyen gjør i sin artikkel. En slik kritikk påbegynner jeg i punkt 2, hvor jeg tegner opp én mulig, enkel og intuitiv, tilnærming til de to spørsmålene nevnt over. Denne har klare islett av vurderinger de lege ferenda, og er også ment å få frem noen skjulte, men viktige nyanser, samtidig som den utfyller $\varnothing$ yens kritiske merknader.

Om $\varnothing$ yens kritikk av Høyesteretts rettskildebruk er jeg mer i tvil. Høyesterett trakk sine slutninger fra kildene; $\varnothing$ yen trekker andre. Samtidig som jeg har sympati for hans argumenter og de reelle hensyn han peker på, har jeg vanskelig for å se noe fellende i hans kritikk. Og dersom vi søker en forklaring på den uheldige rettstilstand som Høyesteretts nye avgjørelse, tilsynelatende, har skapt, synes det mer nærliggende å peke på selve kravbegrepet enn på $\mathrm{H} \varnothing$ yesteretts juridiske metode. Kravet er en juridisk fiksjon (punkt 3). Et grunnleggende spørsmål er om ikke begrepet har blitt så abstrakt at det står i veien for utfoldelsen av den sunne juridiske fornuft som ofte kjennetegner Høyesteretts

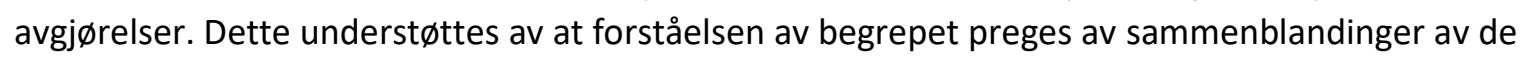
ulike avgrensningsfunksjoner som termen er ment å tjene, av mangelfulle analyser i forarbeidene og av en mangel på dyptloddende rettsvitenskapelige analyser mer generelt. Jeg utdyper dette i punkt 4 og 5 , hvor jeg kritiserer rådende oppfatninger om kravets identitet, som var bestemmende for utfallet i HR-2018-1130-A, og argumenterer for en mer nyanserik tilnærming til problemkomplekset. Denne kritikken underst $\varnothing$ tter at behovet for rettsavklaring ikke har blitt mindre etter kjennelsen fra 2018. Oppgaven kan imidlertid ikke falle på Høyesterett alene; etableringen av mer velbegrunnede og presise regler og retningslinjer må være en oppgave for rettsvitenskapen (punkt 6).

\section{Enkelt og intuitivt (de lege ferenda)}

En forholdsvis enkel og intuitiv måte å tenke om de ovennevnte spørsmål er som følger:

Vil dom på betaling for et utført tjenesteoppdrag sperre for et senere krav om prisavslag fra kjøper? Nei. På samme måte som kjøper ikke taper sin rett til å kreve prisavslag for mangler ved å betale tjenesteyters regning, taper han heller ikke denne retten ved å få dom på betaling mot seg. En slik dom forutsetter ikke at saksøker kan godtgjøre at det utførte arbeidet er uten mangler, for dette er ikke et ubetinget vilkår for rettsvirkningen. En dom på betaling vil derfor alene ikke kunne sperre for et senere krav om prisavslag.

En første reservasjon må gjøres for de tilfeller der saksøkte gjør gjeldende den innsigelse, eller det motkrav, at prisen må justeres på grunn av mangler. Hvis retten kommer til at innsigelsen ikke er holdbar, kan saksøkte naturlig nok ikke fremme et tilsvarende mangelskrav i en senere sak.

Høyesterett viste i denne forbindelse til at det blant annet i Rt. 2012 s. 1138 avsnitt 12 er uttalt at (konstateringen av) hvilket krav som ble avgjort i den tidligere saken, beror på en tolkning (avsnitt 32). Dette bør ikke leses som stort mer enn en truisme: For å konstatere hva som ble avgjort i den tidligere saken, må vi forstå avgjørelsen, og for å forstå den må den tolkes. Uttalelsen bør ikke leses slik at den gir grunnlag for å innfortolke mer i den tidligere saken enn det den faktisk avgjør.

I vår sak fremholdt $\mathrm{H} \varnothing$ yesterett at det i epostutvekslingen som var vedlagt forliksklagen, fremgikk uttrykkelig at kjøperen hadde tilbakeholdt betalingen på grunn av påståtte forsinkelser og mangler, og at dette var årsaken til at rørleggeren tok ut forliksklage (avsnitt 36). Men kjøper mottok ikke

\footnotetext{
${ }^{3}$ Ibid., s. 503.
} 
klagen, og leverte ikke tilsvar (avsnitt 4). Etter hva jeg kan forstå, var en innsigelse om kontraktsbrudd derfor aldri fremmet av saks økte for forliksrådet. Om en slik innsigelse ikke er fremmet av saksøkte, kan dette heller ikke være noe retten skal ta stilling til, jf. tvisteloven $\S 11-2$ første ledd. Uansett hvilke innsigelser kjøper gjør gjeldende overfor tjenesteyters originale krav om betaling, og uansett hva årsaken til en forliksklage/stevning således måtte være, er det naturlig nok opp til kjøper selv å vurdere hvilke innsigelser han vil gjøre gjeldende ved behandling av saken i forliksrådet eller for domstolene. Ifølge Høyesterett var det imidlertid

«reglane om fråværsdom, jf. tvistelova § 16-10 andre ledd, som gjorde at forliksrådet ikkje tok uttrykkeleg stilling til motsegnene om kontraktsbrot og med det om tilbakehaldet var rettmessig eller ikkje» (avsnitt 36, min utheving).

Uansett årsak, om en tidligere instans ikke har tatt (uttrykkelig) stilling til en innsigelse (i premissene eller i domsslutningen, domsslutninger i fraværsdommer inkludert), kan den ikke anses avgjort ved denne instansens behandling. ${ }^{4}$

Som det fremkommer i forarbeidene, og som også Høyesterett viste til (avsnitt 22), må det gjøres en ytterligere reservasjon for «innsigelser som er så nær knyttet til hovedkravet at de må anses som argumenter mot dette som ikke støtter seg til et selvstendig rettsforhold». ${ }^{5}$ Dette lyder så teknisk og abstrakt, samtidig som det er sirkulært og vagt (hva ligger i «så nær knyttet til»?), at det er vanskelig å få tak på. Men jeg tenker at vi, med et forbehold for visse prejudisielle rettsforhold, kan si at essensen i dette er at forutsetningene for et avgjort krav ikke kan angripes i en ny sak. Enkelt sagt vil et krav om X kroner i betaling for et utført tjenesteoppdrag normalt forutsette at partene har inngått en avtale om oppdraget, at oppdraget er utført, og at X etter kontrakten er korrekt betaling for det utførte arbeidet. Blir kravet rettskraftig opprettholdt, er det vel forholdsvis klart at det $\mathrm{i}$ utgangspunktet ikke kan reises ny sak med krav om tilbakebetaling på det grunnlag at partene aldri hadde inngått en avtale, at det avtalte oppdraget ikke er utført, eller at rett betaling etter kontrakten skulle vært Y. At arbeidet er fritt for mangler (som selvsagt ofte først vil kunne vise seg senere), er ikke en slik forutsetning.

Her må det tilføyes at forarbeidene umiddelbart fortsetter med å vise til et nedenforliggende eksempel, hvor den motsatte forståelse tilsynelatende, noe forsiktig, legges til grunn:

«Selgerens krav på betaling av kjøpesummen er som utgangspunkt samme rettsforhold som kjøperens krav om prisavslag, idet prisavslagskravet anses som en innsigelse mot vederlagskravets størrelse, og ikke som et motkrav knyttet til et selvstendig rettsforhold. Iallfall er det oppslutning om denne løsningen i teorien, og den har fått tilslutning i Rt. 2000 side 1420..1 ${ }^{6}$

Jeg kommer tilbake til Rt. 2000 s. 1420 i punkt 4. Den gjaldt et annet spørsmål, og er dessuten ikke presist gjengitt i forarbeidene. Det er derfor tvilsomt om vi bør legge noen vekt på denne, eller på eksempelet i forarbeidene, ved vurderingen av vårt spørsmål. Her nøyer jeg meg med å påpeke at det, intuitivt, kan hevdes å være en viktig forskjell mellom et krav om «prisavslag» etter avtalen og et krav om prisavslag etter kontraktsretten. Ett spørsmål er hva tjenesteyter etter avtalen har krav på for det utførte arbeidet. Hvis det er avgjort at dette beløpet er X, kan kjøper presumptivt ikke i en

\footnotetext{
${ }^{4}$ I denne retning også Rt. 1965 s. 1362, på s. 1363: «... når det skal tas standpunkt til hva som er rettskraftig avgjort ved uteblivelsesdommen, kan det ikke bygges på opplysninger som ligger utenfor klagen og dommen». Se også Rt. 1966 s. 505. Sml. HR-2018-1130-A avsnitt 27.

${ }^{5}$ NOU 2001: 32A Rett på sak, s. 381.

6 Ibid., s. 384.
} 
senere sak gjøre gjeldende at det skulle vært $Y$ på grunn av en bestemmelse om vederlagsjustering («prisavslag») i avtalen eller med grunnlag i generelle avtalerettslige prinsipper om tolkning og utfylling av avtalen, for slike innsigelser er uforenlige med forutsetningene for avgjørelsen i den første saken. Et annet spørsmål er hvilke krav, herunder krav om prisavslag, kjøper kan gjøre gjeldende etter kontraktsretten dersom det viser seg at det foreligger en mangel. Dette er et selvstendig rettsforhold, uansett om mangelen viser seg før eller etter (dom på) betaling. Noen former for krav om «prisavslag» kan således anses som innsigelser mot vederlagskravets st $ø$ rrelse, mens andre er selvstendige rettsforhold.

Skal et krav om prisavslag og et krav om erstatning anses som samme «krav»? Svaret er at det ikke er dette spørsmålet man bør stille.

La oss anta at kjøper av et nyoppført bolighus fremmer mangelskrav mot entrepren $\varnothing r e n$. Kjøper mener at flisene på badet ikke samsvarer med det som er avtalt, og krever erstatning for det $\emptyset$ konomiske tapet som følger med de gale flisene og deres lavere estetiske verdi.

Scenario 1: Retten finner i sin vurdering at kjøpers krav er basert på en uriktig tolkning av avtalen. Flisene er i samsvar med det avtalte. Badet har ingen mangel, og kjøper ikke noe krav på erstatning. Kjøper velger ikke å anke, men angrer seg siden. Bør han da kunne fremme ny sak med krav om prisavslag for den samme påståtte mangelen? Sterke reelle hensyn taler for at svaret på det må være et klart nei.

Scenario 2: Retten holder med saks $\varnothing$ ker $\mathrm{i}$ at flisene ikke samsvarer med det avtalte, og at dette utgjør en mangel. Retten konkluderer imidlertid med at mangelen, selv om den representerer en subjektiv verdireduksjon for kjøper, ikke har påvirket boligens markedsverdi. Kjøper har derfor ikke lidd et $\varnothing$ konomisk tap, og får ikke medhold. Like etter at dommen er avsagt, avsier Høyesterett sin dom $\mathrm{i}$ HR-2018-392-A. Her fant retten, noe overraskende og under dissens 3-2, at det etter bustadoppføringslova $\S 33$ andre ledd, hvoretter det etter ordlyden kan kreves prisavslag for verdireduksjon, er adgang til å utmåle skjønnsmessig prisavslag for den subjektive verdireduksjonen en mangel representerer for kjøper. Bør kjøper i dette scenarioet kunne fremme et nytt krav om prisavslag for mangelen? Jeg er tilbøyelig til å mene det.

Forskjellen mellom de to scenarioene er denne: I det første ville kjøper ikke fått medhold i et krav om prisavslag dersom dette var fremmet i den første saken, med nøyaktig samme begrunnelse som han ikke fikk medhold i sitt krav om erstatning. I det andre ville kjøper fått medhold (såfremt Høyesteretts tolkning ble lagt til grunn). Tilsvarende situasjon vil generelt kunne oppstå når vilkårene for to krav delvis overlapper, eller når vilkårene for det ene er strengere enn vilkårene for det andre.

Dette fremstår også som en relevant forskjell mellom scenarioene, som tapes av syne når problemstillingen formuleres som et spørsmål om krav om erstatning og prisavslag er samme «krav», og som forutsettes å ha ett allmenngyldig svar. Riktignok kan det argumenteres for at de to scenarioene bør løses likt, men det krever en begrunnelse som lodder dypere enn en simpel konstatering av at krav om erstatning og krav om prisavslag er samme «krav».

Prosess $\varnothing$ konomiske hensyn kan tas til inntekt for at kjøper heller ikke i scenario 2 bør kunne fremme et nytt krav om prisavslag. Likhetene mellom kravene gjør en samlet behandling hensiktsmessig, og en regel som prekluderer behandling av det alternative kravet i en ny sak, vil kunne medføre at overflødige saksanlegg unngås. På den annen side kan en slik regel, som gir et insentiv til behandling av flere alternative krav i samme sak, medføre at sakene blir mer omfattende. Så prosess økonomiske hensyn trekker i begge retninger, og det er vanskelig å si hva de samlet sett dikterer. 
Normalt vil det også, selv uten et slikt insentiv, være i partenes egen interesse å fremme de alternative kravene i samme sak. Og årsakene til at to alternative krav, i fravær av et slikt insentiv, ikke gjøres gjeldende i samme sak, kan ligge i en uklar rettstilstand, eventuelt i kombinasjon med mangelfull veiledning fra retten, jf. tvisteloven $\S 11-5$. Det er derfor tvilsomt om dette er et problem som det er noe behov for eller som det er rimelig å reagere mot.

Slik Øyen peker på, vil rettstekniske hensyn og hensynet til forutberegnelighet for partene også stille krav til formuleringen og formidlingen av slike regler som prekluderer behandling av alternative krav. Det mest tungtveiende, slik jeg ser det, må imidlertid bli rimelighets- og rettferdighetshensyn. Et av prosessrettens grunnleggende formål har alltid vært realiseringen av den materielle retten, jf. også tvisteloven § 1-1 første ledd. Prosessuelle regler som medfører at rettmessige materielle krav går tapt, bør møtes med skepsis, særlig der de ikke følger av klare lovbestemmelser og heller ikke har solid støtte i andre tungtveiende hensyn.

\section{Kravet som juridisk fiksjon}

Refleksjonene over anser jeg å være uttrykk for en intuitiv juridisk fornuft; vurderinger langs disse linjer kunne visselig vært lagt til grunn også av Høyesterett. Alene er de imidlertid litt for selektive og frirettslige til at de kan anses avgjørende. Relevant er også det som vi vel må kunne kalle en lære om hva som utgjør ett og samme krav (læren om kravets identitet), som har utviklet seg gjennom rettspraksis, teori og forarbeider. Det er denne læren som bidrar til at det gir mening å spørre om to prima facie ulike krav - slik som et krav om prisavslag og et krav om erstatning - allikevel må regnes som det samme kravet. Et potensielt problem ved denne læren, som jeg med denne artikkelen $\varnothing n s k e r$ å adressere, er at det ikke finnes noe slikt krav.

Det finnes rettsregler, med rettslige vilkår, som anvendes og som partene bygger sine påstander på. Det finnes faktiske forhold som påberopes og som rettsreglene får anvendelse på. Og det finnes påstander som partene nedlegger (som mer naturlig kunne kalles «krav» - men det er ikke slik ordet benyttes i sivilprosessen), og avgjørelser som i mer eller mindre grad overlapper med påstandene. Dette er de relevante, eksisterende st $\varnothing$ rrelser som figurerer på den tankens scene hvor rettsspørsmål drøftes og avgjøres. Det finnes ingen krav.

Til dette kan det saktens spørres om ikke disse st $\varnothing$ rrelsene er kravets byggesteiner. Er det kanskje ikke slik at rettsreglene, påberopte faktiske forhold og de rettsvirkninger som anføres og tilkjennes, til sammen konstituerer (hypotetiske) rettslige krav; det vil si: rettsforhold? I så fall eksisterer også kravet. Til dette ser jeg liten grunn til å protestere. ${ }^{7}$ Men selve problemstillingen forutsetter noe mer enn dette. Når man spør om et krav om prisavslag og et krav om erstatning er det samme kravet, forutsetter man ikke bare at det eksisterer et krav om prisavslag og et krav om erstatning, men at det også eksisterer en ytterligere størrelse, som utgjør den målestokk som de to kravene holdes opp mot for å vurdere om de allikevel er identiske - om de, til tross for sine ulikheter, er det samme Kravet (for å unngå tvetydighet angir jeg det prosessuelle begrepet med stor forbokstav heretter).

Kravet er en metafysisk abstraksjon. Det er en form for juridisk fiksjon, som impliserer at det er noe mer der, men det er det jo ikke. Og hvis Kravet ikke eksisterer, blir spørsmålet om dette er en nyttig fiksjon, som vi er tjent med å beholde, eller om det tvert imot er slik at denne fiksjonen blir for

\footnotetext{
${ }^{7}$ Min kritikk er altså ikke rettet mot kravbegrepet som sådan, som har vært kritisert tidligere i norsk rettsvitenskap, blant annet av Per Augdahl, som omtalte «[d]en besynderlige tro på et slikt mystisk krav [som] har influert på uttrykksmåten i diverse bestemmelser i [tvistemålsloven]", se Per Augdahl, Den norske civilprosess, 3. utgave, Trondheim 1961, s. 28, se også s. 132n. Se mer utførlig, Anne Robberstad, Rettskraft, Bergen 2006, s. 122-130.
} 
abstrakt, og at den står i veien for utfoldelsen av den sunne juridiske fornuft, som forutsetter et språk som er klart nok til at virkeligheten og jussen ikke fordunkles.

Juridiske fiksjoner er et tilbakevendende tema i rettsfilosofien. ${ }^{8}$ Hvordan begrepet skal defineres, og i det hele tatt hva som er paradigmatiske eksempler på juridiske fiksjoner, finnes det forskjellige oppfatninger om i litteraturen. ${ }^{9}$ For Lon L. Fuller var de typisk «nyttige usannheter». ${ }^{10}$ - Rudolf von Jhering kalte dem «jussens hvite løgner». ${ }^{11}$ - Slik sett kunne vi betraktet forestillingen om at et krav om prisavslag og et krav om erstatning er det samme kravet, som én juridisk fiksjon. Dette er en usannhet - for det er jo opplagt forskjellige krav - men det kan være nyttig å late som om de allikevel er identiske. Tilsvarende forestillinger kunne vi betraktet som separate juridiske fiksjoner. For mitt formål her velger jeg imidlertid å kalle Kravet for en juridisk fiksjon, for å få frem dette begrepets problematiske, abstrakte natur, som leder til et spørsmål om det er andre, og bedre, måter å formulere rettsreglene (og vår forståelse av disse) på. Dette var også en sentral problemstilling hos Fuller: «What should we do about the fiction? Should we attempt to restate the law 'in terms of reality'? Could we succeed in such an attempt? ${ }^{12}$

\section{Et krav er et krav er et krav er et krav}

En første indikasjon på at Kravet er en problematisk juridisk fiksjon, har å gjøre med de ulike roller ordet «krav» spiller i tvisteloven. Retten skal ikke bare avvise en ny sak mellom samme parter om et «krav» som er rettskraftig avgjort, jf. tvisteloven § 19-15 (3), men også ny sak mellom samme parter om et «krav» som allerede er tvistegjenstand, jf. § 18-1 om litispendens. Ordet er også bestemmende for hvilke endringer i en parts prosessopplegg som er tillatt, jf. § 9-16, hva retten har kompetanse til å avgjøre, jf. § 11-2, og hva som kan behandles i ankesaken, jf. § 29-4. Disse forskjellige bestemmelsene bygger til dels på forskjellige hensyn, og det kan derfor være problematisk når en avgjørelse om hva som utgjør samme «krav» i relasjon til én av bestemmelsene, brukes som et premiss ved vurderingen av hva som skal utgjøre samme «krav» i relasjon til en annen.

Ordets ulike roller og deres bakenforliggende hensyn kan belyses med et par relevante eksempler fra rettspraksis:

Spørsmålet i Rt. 2000 s. 199 Pelsdyrhall var om det ved ankebehandlingen i Høyesterett var adgang til å fremme et nytt krav om erstatning, ved siden av det krav om prisavslag (begge etter avhendingsloven) som var behandlet av lagmannsretten. Etter tvistemålsloven $\S 366$ annet ledd kunne krav som ikke er påkjent i dommen, ikke fremsettes i ankeinstansen. Spørsmålet var derfor om de to kravene måtte anses identiske i relasjon til denne bestemmelsen.

I sin tolkning viste førstvoterende Gussgard, som representant for flertallet (3-2), blant annet til en uttalelse fra Rt. 1997 s. 1477 om bakgrunnen for bestemmelsen:

«Hensynene bak tvistemålsloven § 366 annet ledd knytter seg både til ankemotparten og til formålet med instansrekkefølgen. Det er dommen i den tidligere rettsinstans som skal overprøves i ankeinstansen. Dette er et grunnleggende forhold som blant annet skal hindre spekulasjon i hva det er hensiktsmessig å forelegge for underinstansen. Bestemmelsen beskytter ankemotparten mot å måtte forholde seg til nye rettsforhold i ankeinstansen, noe

\footnotetext{
${ }^{8}$ Se blant annet L. L. Fuller, «Legal Fictions», Illinois Law Review 25, 1930-1931 s. 363-399; 513-546; 877-910, og Maksymilian Del Mar og William Twining (red.), Legal Fictions in Theory and Practice, Cham 2015.

${ }^{9}$ Se Maksymilian Del Mar, «Introducing Fictions: Examples, Functions, Definitions and Evaluations», i Del Mar og Twining (red.) 2015, s. ix-xxix.

${ }^{10}$ Fuller 1930-1931, s. 369.

11 Ibid., s. 366.

12 Ibid.
} 
som blant annet har betydning for bevisopplegget og for mulighetene til å få ankeinstansens dom overprøvet. ${ }^{13}$

Til dette tilføyde hun:

«l tillegg til dette vil jeg også nevne et prosessøkonomisk aspekt. Spørsmålet om en dom bør påankes, og for motparten hvordan en vil stille seg til en anke, vil i praksis blant annet bli vurdert i forhold til omkostningene ved en ankeforhandling. Etter at dom foreligger, vil partene ha et visst grunnlag for å vurdere disse. I den grad nye krav tillates fremmet i ankeinstansen, kan det føre til en $\varnothing \mathrm{kt}$ og lite rimelig usikkerhet ved denne vurdering. ${ }^{14}$

Deretter sammenlignet hun de to kontraktsbruddsanksjonene før hun trakk sin konklusjon:

«Forskjellen i vilkårene for et erstatningskrav, henholdsvis krav om prisavslag, og forskjellen i utmålingen av kravene, må etter min mening tillegges avgjørende vekt ved vurderingen av om en står overfor samme krav i relasjon til tvistemålsloven § 366 . Dersom prisavslag og erstatning anses som samme krav, kan selgeren $i$ ankeinstansen stå overfor et krav av et helt annet omfang enn det saken dreide seg om i underinstansen, og muligheten for overprøving blir sterkt berørt. Det er dette $\S 366$ tar sikte på å forhindre. Jeg mener derfor at kravet om erstatning må anses som et annet krav enn kravet om prisavslag. [...] $)^{15}$

På den annen side er det, slik mindretallet kom inn på, ${ }^{16}$ betraktelige likheter mellom de to grunnlagene og, både praktisk og prosessøkonomisk, en klar fordel om de behandles samlet. Løsningen er derfor ikke opplagt. ${ }^{17}$ Jeg synes allikevel at flertallets konklusjon har de beste grunner for seg. Saksøkte er i stor grad tvunget til å reagere på saksøkers handlinger, og det kan være at det har kommet til sak utelukkende fordi han bestrider det krav saksøker faktisk har fremmet; hadde han fremmet et annet, kan det være saken for lengst hadde vært forlikt. Det kan derfor virke urimelig om saksøker for $\mathrm{H} \varnothing$ yesterett skal kunne gjøre gjeldende krav B etter å ha prosedert krav A gjennom to instanser. Dette gjelder også når det er klare likheter mellom A og B. At partene bærer risikoen for de valg de tar i forbindelse med prosessen, er på sett og vis en del av gamet, og særlig hensynet til partenes forutberegnelighet taler dermed for at det bør være en meget snever adgang til å trekke inn nye krav ved en ankeforhandling, ikke minst for $\mathrm{H} \varnothing$ yesterett.

Ved sakens begynnelse, når partene har investert mindre i prosessen, bør ikke dette hensynet, og heller ikke hensynet til instansrekkefølgen, ha den samme tyngden. Det kan dermed synes mindre betenkelig å tillate en utvidelse av saken etter saksforberedelsen i første instans (jf. tvisteloven § 916), enn det er å tillate en utvidelse av saken etter anke. Etter saksforberedelsen, og ikke minst ved domsavsigelsen (jf. tvisteloven § 11-2), er det i første rekke hensynene til forsvarlig saksopplysning og kontradiksjon som kan begrunne at saken begrenses til de krav som allerede eller formelt er fremmet.

\footnotetext{
${ }^{13}$ Rt. 2000 s. 199, på s. 203.

14 Ibid.

15 Ibid., s. 204.

${ }^{16}$ Ibid., s. 208-209.

17 Jo Hov mener flertallets oppfatning er «åpenbart riktig», se Jo Hov, Rettergang II, Oslo 2010, s. 1246; Jo Hov, Rettergang i sivile saker, 3. utgave, Oslo 2017, s. 420. Sml. Jens Edvin A. Skoghøy, Tvisteløsning, 3. utgave, Oslo 2017, s. 1086.
} 
Saken i Rt. 2000 s. 1420 gjaldt en tvist mellom en forbruker og et bilverksted. Førstnevnte hadde allerede fremmet klage over sistnevntes reparasjon til Forbrukerrådet, med krav om prisavslag eller erstatning, da verkstedet tok ut stevning med krav om betaling for reparasjonen. $\mathrm{H} \varnothing$ yesterett kom til at verkstedets krav om betaling var samme Krav som forbrukerens krav om prisavslag/erstatning, slik at $s \varnothing \mathrm{ksmålet} \mathrm{måtte} \mathrm{avvises.}{ }^{18}$

Som nevnt over ble denne kjennelsen i forarbeidene tatt til inntekt for at kravene var identiske «idet prisavslagskravet anses som en innsigelse mot vederlagskravets størrelse, og ikke som et motkrav knyttet til et selvstendig rettsforhold $\gg .{ }^{19}$ Noen slik begrunnelse fremkommer ikke i kjennelsen, og den gjaldt altså et spørsmål om litispendens, ikke et spørsmål om rettskraft. Dessuten var ikke spørsmålet for $\mathrm{H} \varnothing$ yesterett om et krav om prisavslag er samme Krav som et krav om betaling (slik sitatet fra forarbeidene forutsetter, og slik tilfellet var i HR-2018-1130-A). I saken fra 2000 var det kravet om prisavslag som var litispendent. Spørsmålet var derfor, mer presist, det omvendte: Om et krav om betaling er samme Krav som et krav om prisavslag (for to spesifikke sådanne krav, i relasjon til regelen om litispendens).

$\mathrm{H} \varnothing$ yesterett gav ingen begrunnelse for sin konklusjon. Med et par henvisninger til juridisk litteratur konstateres det simpelthen:

«Begge krav springer ut av samme kontraktsforhold, og realiteten i den saken som Endresen har brakt inn for Forbrukerrådet er at han mener at Oppsal Bilservice AS ikke har krav på fullt vederlag fordi servicen/reparasjonen er mangelfullt utført. I et slikt tilfelle må et krav om prisavslag/erstatning anses som samme 'tvistgjenstand' [...]». ${ }^{20}$

Her er jeg mer enig med Høyesterett i gavnet enn i navnet. Resultatet er rimelig, forklaringen synes fordekt. Formålet med litispendensreglene er å unngå dobbeltbehandling av tvister og motstridende avgjørelser om samme rettsforhold. Og saken i Rt. 2000 s. 1420 reiste to spørsmål: Ett var hvilket vederlag verkstedet hadde krav på etter avtalen, et annet var hva forbrukeren kunne kreve som følge av den mangelfulle reparasjonen. Holdes de to atskilt, er det ingen fare for dobbeltbehandling eller motstridende avgjørelser. Det synes derfor lite dekkende å beskrive disse som samme «krav». ${ }^{21}$

At avgjørelsen allikevel virker rimelig, beror på at stevningen med krav om betaling ikke synes å tjene noe annet formål enn å underminere forbrukerens klage til Forbrukerrådet. Det er dessuten slik at forbrukeren, jf. håndverkertjenesteloven $\S 23$, har rett til å holde tilbake så mye av betalingen at det sikrer forbrukerens krav som følge av mangelen. Kravet om betaling ville dermed i praksis ikke kunne bli vurdert uten å ta stilling til mangelskravet. Selv om kravene ikke er identiske, ville behandlingen av det andre altså forutsette behandling av det første. Derfor er også avvisningen rimelig, men det synes mer treffende og transparent å beskrive dette som et tilfelle av utvidet litispendens(virkning).

Et interessant spørsmål i denne forbindelse er hva $\mathrm{H} \varnothing$ yesterett ville besluttet om en omvendt problemstilling oppstod: Etter uenighet om vederlaget tok verkstedet ut stevning med krav om full betaling etter avtalen. På et senere tidspunkt (etter saksforberedelsen; før dommen i første sak er rettskraftig; eller før ankebehandlingen i den første saken) oppdager forbrukeren en mangel og tar ut

\footnotetext{
${ }^{18}$ Mer presist om det var samme «tvist» eller «tvistgjenstand», jf. forbrukertvistloven $\S 15$ første ledd og tvistemålsloven § 63; se Rt. 2000 s. 1420, på s. 1423.

${ }^{19}$ NOU 2001: 32A, s. 384.

${ }^{20}$ Rt. 2000 s. 1420 , på s. 1423.

${ }^{21}$ Slik også Hov 2010, s. 1248. Å beskrive de som samme «tvistgjenstand» virker rett nok rimeligere. Dette ordet hadde, i det minste noen steder i tvistemålsloven, en videre betydning - en tvistgjenstand kunne bestå av flere krav, jf. tvistemålsloven § 9 første ledd og § 365 første ledd nr. 3.
} 
sin egen stevning med krav om prisavslag/erstatning. Ville Høyesterett da avvist den nye saken, til forbrukerens ugunst, med en tilsvarende knapp begrunnelse? Og burde Høyesterett gjort det samme i dag, med henvisning til Rt. 2000 s. 1420, som var til forbrukerens gunst? Ingen av delene er opplagt. Hvis man først gir litispendensregelen utvidet anvendelse, er det ikke alltid grunn til å utvide i begge retninger. Det kan derfor ikke utelukkes at et krav om betaling etter litispendensregelen kan anses identisk med et krav om prisavslag/erstatning, uten at kravet om prisavslag/erstatning må anses identisk med kravet om betaling. Rt. 2000 s. 1420 har derfor en uklar, og etter mitt syn begrenset, overføringsverdi til det omvendte litispendensspørsmålet.

Enda mindre overføringsverdi har avgjørelsen til spørsmål om rettskraft. Riktignok deler reglene om litispendens og rettskraft en felles begrunnelse: Entydige og endelige rettsavgjørelser er prosess- og samfunnsøkonomisk gunstig og bidrar til forutberegnelighet og stabilitet i forholdet mellom partene og i samfunnet for $\varnothing v$ rig. Men det er også forskjeller: Regelen om rettskraft sier at ny sak om et krav som er avgjort, skal avvises. Regelen om litispendens er ment å forhindre behandling av krav som vil, kan eller bør bli avgjort i en allerede verserende sak. En avvisning etter rettskraftregelen kan dermed fattes på et sikkert grunnlag, mens en avvisning etter litispendensregelen (i mange tilfeller) må fattes på et usikkert grunnlag.

For eksempel kan et krav om prisavslag bli avvist fordi det bør behandles, eller kan tenkes å bli behandlet, i samme sak som et krav om betaling, og vice versa, men det er ikke dermed sagt at det faktisk vil bli avgjort. Og hva som rent faktisk er avgjort i en sak, må bero på en tolkning av avgjørelsen i saken, ikke på en vurdering av hvilke krav som burde eller kunne tenkes å ha blitt behandlet i den.

Dessuten varer rettskraften evig, mens litispendensvirkningen ikke rekker lenger enn til rettskraftens inntreden. Derfor er en avvisning av et rettskraftig avgjort krav mer definitiv, og dermed også mer inngripende, enn en avvisning av et krav som er litispendent. Dette taler, sammen med usikkerheten og mulige føre var-betraktninger ved litispendensvurderinger, for at det bør kreves mer solide holdepunkter for å avvise en sak etter rettskraftregelen enn etter litispendensregelen. Dette gjelder særlig når kravene ikke strengt tatt er identiske, som i Rt. 2000 s. 1420: Å avvise verkstedets krav om betaling midlertidig fordi behandlingen av dette forutsetter behandling av forbrukerens mangelskrav, som er litispendent, er én ting. Å avvise kravet for evig tid med den begrunnelse at forbrukeren har fått ett eller annet mangelskrav rettskraftig avgjort, er naturlig nok noe ganske annet; en slik avvisning måtte forutsatt en selvstendig begrunnelse.

Dette mangfoldet av vurderingstemaer og deres bakenforliggende, ulikeartede hensyn taler for at svaret på hva som utgjør ett og samme «krav», ikke nødvendigvis vil være det samme i ordets ulike relasjoner. Hver bestemmelse bør tolkes i lys av de hensyn den er uttrykk for, og det bør utvises stor varsomhet ved vurderingen av hva uttalelser om én av bestemmelsene kan si oss om tolkningen av de $\varnothing$ vrige.

Mot denne bakgrunn er det underlig å lese Tvistemålsutvalgets generelle synspunkter på hva som anses å utgjøre samme Krav. Etter å ha påpekt at spørsmålet kan oppstå i de ovenfor nevnte relasjoner, konstateres det, uten nevneverdig problematisering eller begrunnelse:

«Ut fra konsekvens- eller harmonihensyn kan man gå ut fra at vurderingstemaet vil være det samme i disse relasjonene.. ${ }^{22}$

\footnotetext{
22 NOU 2001: 32A, s. 382.
} 
Tvistemålsutvalget gir uttrykk for at det bare viderefører rettstilstanden etter tvistemålsloven, «uten endringer av betydning». ${ }^{23}$ Men utvalget hadde ikke trengt å se lenger enn til nevnte Pelsdyrhall for en mer nyansert forståelse. Her uttales det, med henvisning til Rt. 1997 s. 1477:

«Det fremgår av avgjørelsen fra 1997 at de hensyn som har ført til den aktuelle lovregel der dette med nye krav har betydning, vil være et sentralt tolkingsmoment. $)^{24}$

Her fremheves altså hensynene bak den aktuelle lovregel. Og at disse er ulikeartede, sies enda tydeligere i avgjørelsen fra 1997, hvor også tvistemålslovens forskjellige formuleringer fremkommer:

«Litispendensvirkningen etter tvistemålsloven $§ 64$ er knyttet til begrepet 'samme tvistegjenstand', mens rettskraftvirkningen etter $\S 163$ gjelder 'et krav, som er avgjort ved retskraftig dom'. Forbudet mot å fremsette nye krav i ankeinstansen gjelder 'Krav, som ikke er paakjendt i dommen'. At innholdet i disse uttrykkene ikke fullt ut er det samme, synes det å være enighet om i teorien, selv om det generelle inntrykk er at det stort sett anses å være overensstemmelse.

Et sentralt tolkningsmoment er de hensyn som har ført til den aktuelle lovregel. Lovgrunnlaget for de ulike bestemmelsene i tvistemålsloven som bruker uttrykk som nevnt, er forskjellig. Det er dermed ikke gitt at de omfatter det samme. At rettskraftsreglene eksempelvis ikke hindrer en ny sak, innebærer således ikke nødvendigvis at kravet må anses som et nytt krav i ankeinstansen. $\nu^{25}$

Det kan se ut til at forarbeidene bygger på en diskutabel forståelse av gjeldende rett, ${ }^{26}$ og at Tvistemålsutvalgets fors $\varnothing \mathrm{k}$ på videreføring har ledet til en utilsiktet endring, eller i det minste har bidratt til at en tidligere omstridt forståelse har festnet seg i den juridiske opinion. Det er påfallende at det i HR-2018-1130-A ikke engang nevnes at Pelsdyrhall gjaldt adgangen til å trekke inn nye krav ved anke. Det er heller ikke nevnt i Rt. 2009 s. 286 eller i Rt. 2012 s. 1138, som kommenterer dommen, og som Høyesterett bygger på i kjennelsen fra 2018. Øyen nevner det heller ikke i sin kritiske gjennomgang av rettspraksis. ${ }^{27} \mathrm{Og}$ i samtlige av sivilprosessens standardverker legges det nå til grunn, uten diskusjon og med svært begrensede forbehold, at identitetsspørsmålet skal løses likt i

\footnotetext{
23 Ibid., s. 419.

24 Rt. 2000 s. 199, på s. 203.

${ }^{25}$ Rt. 1997 s. 1477, på s. 1486 (mine uthevinger).

${ }^{26}$ En tilsynelatende inkonsistens i forarbeidene, som reiser et spørsmål om hva Tvistemålsutvalget kan ha ment med uttalelsen i kapitlet om rettskraft, om at "vurderingstemaet vil være det samme i disse relasjonene», er at utvalget i punkt 20.2 om litispendens, etter å ha vist til Rt. 1997 s. 1477, konkluderer med at det blir «enkelte forskjeller mellom rettskraftens objektive grense og grensene for litispendens», se NOU 2001: 32B, s. 872. Den samme tilsynelatende inkonsistens gjenfinnes i Ot.prp. nr. 51 (2004-2005) Om lov om mekling og rettergang i sivile tvister (tvisteloven). Ingen av høringsinstansene innga merknader til utvalgets generelle syn på rettskraftens objektive grenser, og departementet sier seg enig i utvalgets vurderinger om disse spørsmålene, se Ot.prp. nr. 51 (2004-2005), s. 259 og 441. I merknaden til § 18-1 bekreftes det imidlertid at «det ikke helt ut [er] de samme hensyn som ligger bak reglene om litispendens og rettskraft, slik at det kan tenkes at identitetsspørsmålet blir løst forskjellig, se for eksempel Rt. 1997 s. 1477», jf. ibid., s. 432. Jeg kan ikke se at denne inkonsistensen er kommentert i rettspraksis eller i juridisk litteratur; her er det uttalelsene om rettskraft som trekkes frem og tas til inntekt for en enhetlig løsning på identitetsspørsmålet.

${ }^{27} \varnothing$ yen 2018, s. 501-503.
} 
disse ulike relasjonene. ${ }^{28}$ Viktige nyanser som med god grunn ble tillagt vekt i tidligere rettspraksis og juridisk teori, ser ut til å ha blitt visket ut fra ordskiftet.

Den mest dyptloddende behandling av emnet i norsk rettsvitenskap er Torstein Eckhoffs doktoravhandling Rettskraft, fra 1945. Her var han helt tydelig på at identitetsspørsmålet ikke kunne løses likt i alle sammenhenger. Hans behandling av spørsmålet er kortfattet, og han gir kun én illustrasjon, men det skyldes nok bare at han oppfattet dette som så selvsagt at det ikke krevde nærmere drøftelser (selv i en avhandling på 400 sider): «Det kan virke villedende at alle disse rettsvirkninger knyttes sammen ved bruken av samme begrep, for det synes klart at de spørsmål som reiser seg til dels må løses forskjellig.» ${ }^{29}$

Eckhoff så også tydelig det faremoment som følger med bruken av det samme ordet $\mathrm{i}$ ulike relasjoner. Han advarte mot at «en gjerne kommer for lettvint til resultatene, når en tror å gi en begrunnelse ved å skyte inn et uklart begrep. Og begrepet domskrav har en særlig ulempe, idet det medfører fare for at språklige assosiasjoner skal øve innflytelse på spørsmålenes løsning. Det er jo ikke så lett i en fart å holde ut fra hverandre alle de forskjellige, men beslektede, 'materielle' og 'prosessuelle' kravsbegreper..1 ${ }^{30}$

Anne Robberstad, som i sin bok Rettskraft gir den grundigste behandling av emnet i nyere tid, innvender at Eckhoffs ene eksempel, om ulike skilsmissegrunner, er «upraktisk og alderdommelig». ${ }^{31}$ Hun avfeier også uttalelsene i Rt. 1997 s. 1477 som «teoretiserende betraktninger» fra Høyesterett. ${ }^{32}$ Som st $\varnothing t t e$ for sin konklusjon om at hva som utgjør ett og samme krav, «må løses likt» i disse ulike relasjonene, viser hun til Rt. 2002 s. 945, hvor det på s. 947, med litt andre ord, ble uttalt at spørsmålet ved litispendens «må avgjøres på grunnlag av de samme kriterier som for rettskraft, jf. Rt-1999-1177» (min utheving). Og i avgjørelsen fra 1999 står det bare, på s. 1178 (min utheving): «Det må antas at identitetsspørsmålet $i$ utgangspunktet må løses likt i de forskjellige sammenhengene.» I motsetning til hva sitatet fra Pelsdyrhall over med henvisning til Rt. 1997 s. 1477 indikerer, tar hun også denne avgjørelsen til inntekt for et enhetlig kravbegrep. Hun påpeker at flertallet (og mindretallet tilsvarende, med motsatte fortegn) i sin argumentasjon for at kravet om erstatning ikke kunne fremmes for ankeinstansen, la til grunn at «reglene om rettskraft ikke stenger for ny sak om erstatning for den del av kravet som ikke dekkes etter reglene om prisavslag». ${ }^{33}$ Dette viser én mulig sammenheng mellom reglene: Hvis det er adgang til å fremme kravet $i$ en ny sak, er det mindre grunn til å tillate det fremmet i ankeinstansen. Og motsatt: Hvis det ikke er adgang til å fremme kravet i en ny sak, er det i større grad grunn til å tillate det fremmet i ankeinstansen. At det er én sammenheng mellom reglene, eller at man tolker reglene i sammenheng, medfører imidlertid ikke at svaret på hva som utgjør ett og samme «krav», må være det samme i alle sammenhenger.

Utover dette er Robberstads egen begrunnelse for et enhetlig kravbegrep at det vil være «ugreit» om ordet «krav» ikke betydde det samme overalt i loven, ${ }^{34}$ og at et enhetlig kravbegrep er den beste løsningen «for å unngå det kaos som kan bli resultatet dersom fastleggingen av hvert enkelt kravs 'identitet' ikke skal være den samme i forhold til alle bestemmelsene». ${ }^{35}$ Et slikt argument overser at spørsmålet faktisk ikke dreier seg om betydningen til ordet «krav», i det minste ikke på en direkte måte; det angår ikke hva et krav er. Identitetsspørsmålet angår den juridiske fiksjonen Kravet - en langt mer flyktig størrelse - som innebærer at to ulike krav kan anses identiske (se nærmere i neste punkt). Og grunnene til at to ulike krav bør anses

\footnotetext{
${ }^{28}$ Inge Lorange Backer, Norsk sivilprosess, Oslo 2015, s. 339; Anne Robberstad, Sivilprosess, 4. utgave, Bergen 2018, s. 378; Tore Schei mfl., Tvisteloven: Kommentarutgave, bind I, 2. utgave, Oslo 2013, s. 678 (Schei var Tvistemålsutvalgets leder); Skoghøy 2017, s. 1081. Mindre tydelig på dette er Hov 2010, s. 1241; Hov 2017, s. 417. Jens Edvin A. Skoghøy inntok relativt tidlig dette standpunktet, uten begrunnelse, se Skoghøy, «Rettskraftens objektive grenser i sivile saker», Jussens Venner, 1995 s. 1-64, på s. 39-40. Se også den mer utførlige vurderingen i Robberstad 2006, s. 134-138.

${ }^{29}$ Torstein Eckhoff, Rettskraft, Oslo 1945, s. 59.

${ }^{30} \mathrm{lbid}$.

${ }^{31}$ Robberstad 2006, s. 136.

${ }^{32}$ Ibid., s. 137.

${ }^{33}$ Ibid.; Rt. 2000 s. 199, på s. 204.

${ }^{34}$ Robberstad 2006, s. 135.

35 Ibid., s. 138.
} 
identiske, er ikke nødvendigvis de samme, og gjør seg ikke nødvendigvis gjeldende med samme tyngde, i disse ulike relasjonene.

Det er i denne ensrettingen vi finner årsaken til at Høyesterett i HR-2018-1130-A, med henvisning til forarbeidene, uten videre la til grunn at et krav om prisavslag er samme Krav som et krav om betaling. Ordet «krav» (og tvistemålslovens korresponderende, men ulike, formuleringer) ble antatt å ha samme innhold $\mathrm{i}$ lovens forskjellige bestemmelser. Hvis krav om prisavslag og betaling anses identiske i relasjon til regelen om litispendens, må de derfor også være identiske i relasjon til regelen om rettskraft.

Som min gjennomgang over antyder, er dette i beste fall tvilsom argumentasjon. Det er et eksempel på det Eckhoff advarte mot: at «en gjerne kommer for lettvint til resultatene, når en tror å gi en begrunnelse ved å skyte inn et uklart begrep». ${ }^{36}$ Uansett hvordan man vrir og vender på det: Det at et verksted ikke fikk fremmet sitt krav på betaling mot en forbruker mens dennes mangelskrav var til behandling i Forbrukerrådet, er et tynt argument (et lite relevant prejudikat) for at en annen forbruker skal tape sitt mangelskrav overfor en rørlegger som har fått dom på betaling av sitt avtalte vederlag. Høyesteretts vurdering får et skinn av legitimitet ved at den bygger på en abstrakt lære om hva som utgjør samme Krav. Men det er bare abstraksjonsnivået som er hevet; den underliggende argumentasjonen forblir tvilsom.

Vi finner en lignende slutning i forløperen Rt. 2012 s. 1138. Etter at saks øker i en første sak var tilkjent erstatning for råteskader i takkonstruksjonen på en eiendom som følge av lekkasjer, ble det under utbedringen av skadene oppdaget mer omfattende råteskader. Ett av spørsmålene i saken var om et krav om erstatning for de nyoppdagede tapspostene ville måtte avvises fordi de ulike tapspostene hørte til det samme Kravet. Ankeutvalget ga sin tilslutning til lagmannsretten, som, med støtte utelukkende i Rt. 2006 s. 983, ikke var i tvil om at et slikt krav ville måtte avvises (avsnitt 22-23).

Også i dommen fra 2006 var situasjonen den at kjøper av en eiendom hadde oppdaget mer omfattende skader under utbedringen av en mangel. Spørsmålet her gjaldt imidlertid ikke rettskraft, men om initiale fristavbrytende skritt også hadde avbrutt foreldelsen av de senere oppdagede mangelskrav. I avsnitt 35 og 36, som både lagmannsretten og ankeutvalget siterer (utvalgets avsnitt 16), uttales det blant annet:

«[...] Ikke minst vil omkostninger til utbedring rent teoretisk kunne utgjøre et stort antall enkeltposter, alt avhengig av hvor detaljert kravet settes opp. Praktiske hensyn tilsier at hver enkelt post ikke kan anses som et særskilt krav ved bedømmelsen av spørsmålet om et krav omfattes av et fristavbrytende rettslig skritt som nevnt i foreldelsesloven $\S 15$. [...] For vår sak vil dette i utgangspunktet føre til at foreldelsen både av det mangelskrav som knytter seg til omlegging av taket, og kravet vedrørende utbedring av skader $\mathrm{i}$ nordveggen forårsaket av lekkasjer fra taket, ble avbrutt ved den forliksklage hvor dette kravet ble fremsatt.»

Ankeutvalget nevner at Rt. 2006 s. 983 gjaldt et spørsmål om foreldelse (avsnitt 16), men stiller ikke spørsmål ved avgjørelsens overføringsverdi. Det er betenkelig. Reglene om foreldelse bygger på andre hensyn enn reglene om rettskraft. Det som foreldes etter foreldelsesloven, er materiellrettslige krav, ikke prosessrettslige krav. ${ }^{37}$ Den relevante bestemmelsen i foreldelsesloven $\S 15$ første ledd første punktum nevner ikke engang ordet «krav». Og uansett hvordan man vrir og vender på det: Det at én kjøper fikk medhold i at fristavbrytende skritt knyttet til én tapspost også avbrøt foreldelsen av en relatert tapspost, er

\footnotetext{
${ }^{36}$ Eckhoff 1945, s. 59.

37 Dette er en annen distinksjon enn den distinksjonen mellom materielle og prosessuelle (prosessrettslige) krav som påpekes i Hjort 2018. Se ellers Robberstad 2006, s. 118-138, om ulike kravbegrep.
} 
et tynt argument (et lite relevant prejudikat) for at en annen kjøper som har fått rettskraftig dom for én tapspost, skal tape sin rett til å få dom for en annen. ${ }^{38}$

Det er korrekt, som det sies i den nevnte avgjørelsen fra 1997, at det stort sett vil, og bør, være overensstemmelse mellom vurderingene av hva som i ulike relasjoner utgjør samme «krav». Uoverensstemmelser vil være forbeholdt begrepenes randsoner. Det er her vanskelige spørsmål kan forventes å oppstå. Men det er også slike man kan forvente kommer for Høyesterett. Og det kan derfor være problematisk når en avgjørelse om hva som utgjør ett og samme «krav» i én relasjon, uten videre brukes som et premiss ved vurderingen av hva som utgjør ett og samme «krav» i en annen. HR-2018-1130-A er etter mitt syn et talende eksempel på hvordan en slik transposisjon kan lede til uheldige resultater.

Tvistemålsutvalget påberoper seg konsekvens- og harmonihensyn til støtte for sin forståelse. Dette må enten være uttrykk for en misforståelse av bestemmelsenes bakenforliggende hensyn, eller så er det tale om en harmonisering basert på lovens ordvalg, i stedet for bestemmelsenes formål. En slik overfladisk harmonisering vil kunne medføre at vi får avgjørelser om én bestemmelse som er uttrykk for de bakenforliggende hensyn til en annen. Det skaper ikke harmoni, men disharmoni. Hvilke saker som kommer for Høyesterett, vil også bero på tilfeldigheter. Dermed kan det bli vilkårlig hvilke hensyn som blir de dominerende og får gjennomslag. Og når en ensrettet forståelse møter tilstrekkelig motstand fra konkrete rimelighetshensyn i nye saker, kan den bli så ustabil at den blir satt til side, til fordel for en ny forståelse, som vil kunne være like vilkårlig og ustabil. HR-2018-1130-A illustrerer også dette: Høyesterett kunne ha konstatert at Pelsdyrhall gjaldt et annet spørsmål - nye krav ved anke, i kontrast til rettskraft. Men fordi denne distinksjonen har forsvunnet fra ordskiftet, oppfattes Pelsdyrhall som et relevant prejudikat - spørsmålet er bare om krav om prisavslag og erstatning er samme Krav. Og fordi prejudikatet synes å angi en urimelig løsning for det nye saksforholdet, ender man ganske unødvendig opp med å sette det til side (riktignok uten at dette sies eksplisitt). Forarbeidenes ensretting leder ikke til konsekvens og harmoni, men til vilkårlighet, disharmoni og en ustabil rettsorden.

\section{Viktigheten av å stille de rette spørsmålene}

En annen indikasjon på at Kravet er en problematisk juridisk fiksjon, angår vurderingen av når man står overfor ett eller flere Krav i én bestemt relasjon - generelt, og ved rettskraft spesielt. Hva slags vurdering er dette? Og hvordan skal den gjennomføres? I forarbeidene kan vi lese følgende om dette:

«Avgjørelsen av om man står overfor ett eller flere krav eller rettsforhold, vil måtte skje på grunnlag av en totalbedømmelse av flere forhold. Det viktigste momentet er nok om de rettsfølger som gjøres gjeldende er kvalitativt ulike. Om rettsfølgene er kvalitativt like, begge grunnlag munner for eksempel ut i et pengekrav, vil det være et viktig moment i hvilken utstrekning de kan kumuleres, det vil si gjøres gjeldende ved siden av hverandre. Kumulasjonsadgang tilsier at man står overfor flere krav. Krav som er alternative, slik at det ene utelukker det annet, vil lettere bli ansett for å utgjøre samme rettsforhold. Det er også et moment, om enn mindre viktig, hvorvidt det er vesensforskjell mellom de faktiske vilkårene som må foreligge for at kravet skal inntre. Endring av det rent rettslige grunnlaget for kravet innebærer på den annen side ikke at det skifter identitet. Et

\footnotetext{
${ }^{38}$ Kritisk til en slik kopling mellom prosessreglene og reglene om foreldelse er også Marte Eidsand Kjørven i Kjørven mfl., Foreldelse av fordringer, Oslo 2011, på s. 334-345. Se også Lasse Simonsen, Prisavslag og erstatning for mangler ved fast eiendom, Oslo 2019, s. 68-70.
} 
ytterligere moment er om de interesser rettsreglene tar sikte på å beskytte, i det vesentlige er de samme. Dessuten har tradisjonell oppfatning en viss vekt.. ${ }^{39}$

Ifølge forarbeidene skal man altså foreta en «totalbedømmelse», som jeg antar er en form for avveining, for å konstatere om man står overfor ett eller flere Krav. Og det viktigste momentet i denne avveiningen er om de rettsfølger som gjøres gjeldende, er kvalitativt ulike.

Dette er en oppfatning som i hovedtrekkene samsvarer med gjengse oppfatninger i juridisk teori fra de siste tiårene. ${ }^{40}$ Det er altså ikke en oppfatning som stammer fra Tvistemålsutvalget, ${ }^{41}$ men her er det i liten grad rom for å gå inn på teoriens nyanseforskjeller, og jeg tar utgangspunkt i forarbeidene, som den presumptivt viktigste premissleverand $\varnothing \mathrm{r}$ ved tolkningen av tvisteloven. $\mathrm{H} \varnothing$ yesterett siterer ovennevnte uttalelse både i HR-2018-1130-A (avsnitt 23) og i forgjengeren Rt. 2012 s. 1138 (avsnitt 14), og ser ut til å legge forståelsen til grunn for sin vurdering. Øyen viser også til den samme opplistingen, og skriver at grensedragningen mellom like og ulike krav er «grundig analysert [...] i forarbeidene». ${ }^{42}$

Oppfatningen om at det skal foretas en totalbedømmelse hvor det viktigste momentet er om rettsfølgene er ulike, nyter altså bred anerkjennelse, og den høres kanskje tilforlatelig ut. Men er den holdbar? Gir den i det hele tatt mening? La oss begynne med å sette den på et par intuitive prøver:

La oss først anta at Hansen krever erstatning fra Olsen for en mangel ved en vare, og at han ikke får medhold fordi retten kommer til at varen ikke har en mangel. Kan Hansen da i neste omgang reise ny sak med krav om retting av den påståtte mangelen? Og hvis ikke det går, reise ny sak med krav om omlevering? Og deretter heving? Dette er kvalitativt ulike rettsfølger, og det skal ifølge forarbeidene være det viktigste. Sett hen til all usikkerheten og vaklingen i spørsmålet om prisavslag/erstatning, som har så godt som identiske rettsfølger, kan vel svaret på spørsmålet heller ikke være særlig tvilsomt, om man bygger på forarbeidenes forståelse. Samtidig er det vanskelig å se noen god forklaring på hvorfor et krav om prisavslag skal være avskåret, mens de andre kravene kan fremmes. Og rent normativt - om vi søker en begrunnelse - virker det lite overbevisende å høre at dette skyldes at rettsfølgene til erstatning/prisavslag er relativt like, mens de til erstatning og f.eks. retting er ulike. Normativt synes det å være langt viktigere om rettsvilkårene er (u)like, enn hva som kjennetegner rettsfølgene.

La oss videre anta at vi står overfor to krav som på alle relevante måter ser ut til å ha identiske rettsfølger. Begge er krav på erstatning for mangel, etter den samme bestemmelsen. Vi kan

\footnotetext{
${ }^{39}$ NOU 2001: 32A, s. 382-383 (min utheving). Se også Ot.prp. nr. 51 (2004-2005), s. 258 og 441.

${ }^{40}$ Om identitetsspørsmålet, se Backer 2015, s. 338-346; Hov 2010, s. 1240-1259; Hov 2017, s. 416-427; Robberstad 2006, s. 139-204; Robberstad 2018, s. 384-392; Schei mfl. 2013, s. 678-682; Skoghøy 2017, s. 1080-1100. Robberstad skiller seg ut i dette selskapet med sin mer rettsvitenskapelige og historisk informerte inndeling i ulike metoder: grunnlagsmetoden, rettsfølgemetoden, faktum-metoden og kravtypemetoden. Den siste er hennes egen og foretrukne metode, men som hun innrømmer, gir ingen av metodene svar på samtlige identitetsspørsmål, og hennes systematisering av gjeldende rett synes å lede tilbake til den samme totalbed ømmelse som de øvrige forfatterne forfekter, når hun konkluderer (Robberstad 2018, s. 391): «Det kan synes som om domstolen velger den eller de metodene som raskt gir et svar som passer for det enkelte tilfellet, slik retten synes det bør avgjøres.» Se også Robberstad 2006, s. 169.

${ }^{41}$ Aksentueringen av kvalitativt ulike rettsfølger kan ifølge Jo Hov føres tilbake til hans doktoravhandling (Rettsforlik, Oslo 1976, s. 460 flg.), se Hov 2010, s. 1243n; Hov 2017, s. 419n. Ifølge Robberstad var Hov her tydelig inspirert av Per Olof Ekelöf, se Robberstad 2006, s. 157-159 og spesifikt fotnote 49. Se ellers også Skogh øy 1995, s. 26 flg. Robberstad fant, for $\varnothing v r i g$, i sin metodiske gjennomgang av rettspraksis at Høyesterett hadde vært mer konkret, og mindre metodisk orientert, i rettskraftdommene enn i avgjørelser om de andre relasjonene kravbegrepet inngår i, se Robberstad 2006, s. 160.

$42 \varnothing$ yen 2018, s. 494.
} 
forutsette at begge er gjort gjeldende av Hansen overfor Olsen, og at de begge beløper seg til kroner 1500 . Hva har vel det å si, om de to kravene gjelder forskjellige, samtidige eller suksessive, mangler? Normativt synes det viktigere om reglene får anvendelse på samme/forskjellige faktiske forhold, enn hva som kjennetegner rettsfølgene.

Forarbeidenes fremhevelse av rettsfølgene, og at det viktigste momentet er om disse er kvalitativt ulike, synes normativt sett vanskelig å forsvare. Dette rokker også ved tilliten til at forarbeidenes syntese gir et dekkende bilde av de momenter som har vært ansett som de viktigste i norsk rett.

En utfordring ved vurderingen av dette er at det i forarbeidene ikke finnes noen analyse, og heller ikke noen begrunnelse for syntesen. Man presenteres for den generelle forståelsen, og deretter en rekke eksempler med enkelte utdypende kommentarer. ${ }^{43}$ Noen av disse har henvisninger til rettspraksis, og må antas å utgjøre råmateriale til utvalgets generelle oppfatning, mens andre synes å være uttrykk for den generelle oppfatningen, uten at det alltid er klart hva som er hva. Dessuten vil regler med forskjellige rettsfølger ofte ha forskjellige rettsvilkår. Mange av Tvistemålsutvalgets eksempler - herunder om eiendomsrett/panterett, avskjed/oppsigelse eller ugyldighet/erstatning ${ }^{44}$ gir derfor ikke definitiv støtte til oppfatningen om at ulike rettsfølger er det som har størst betydning; de er like forenelige med at ulike rettsvilkår er det viktigste. Men uansett er det flere av de potensielt avgjørende eksemplene som er egnet til å så tvil om utvalgets forståelse er holdbar. ${ }^{45}$

Noen er uttrykk for en rettsforståelse jeg ikke uten videre kan si meg enig i. For eksempel hevdes det, uten begrunnelse eller rettslig forankring, at krav om eiendomsrett vil være samme Krav uten hensyn til hvilket påstandsgrunnlag - for eksempel kjøp eller hevd - det er basert på. ${ }^{46} \mathrm{Hvis}$ et krav om eiendomsrett basert på hevd er rettskraftig avgjort i saks $\varnothing$ kers disfav $\varnothing$, vil det altså avskjære et senere krav om eiendomsrett basert på en allerede foreliggende kjøpekontrakt (eller et testament, for den saks skyld), fordi Kravet allerede er avgjort. Det låter tvilsomt. ${ }^{47}$

Andre eksempler ser ut til å undervurdere eller underslå betydningen av ulike rettsvilkår. Ifølge utvalgets første eksempel vil to krav om fiskerett i en elv være distinkte Krav om de henholdsvis er

«begrunnet med at man er innehaver av en særrett til fiske i elven (servitutt) som ligger til den eiendom man eier, eller på at det i kraft av lokal sedvanerett gjelder en kollektiv rett til fiske for dem som bor $i$ et bygdelag». ${ }^{48}$

Dette er jeg enig i. Et avgjort krav om fiskerett basert på en servitutt bør ikke kunne sperre for en senere sak om fiskerett basert på lokal sedvanerett. Den mest fremtredende forskjellen mellom disse to tilfellene er imidlertid at rettsgrunnlagene/rettsvilkårene er forskjellige; rettsfølgene kan hevdes å være identiske: en rett til fiske i elven simpliciter.

Videre skriver utvalget om Pelsdyrhall at flertallet her «la vekt på at kravene [sic] riktignok ikke er kvalitativt ulike, men at det er vesentlige forskjeller mellom vilkårene for prisavslag og erstatning, og

\footnotetext{
${ }^{43}$ NOU 2001: 32A, særlig s. 382-386; kapitlet om rettskraft spenner over s. 377-423.

${ }^{44}$ Ibid., s. 383-384 (eksempel A, F og G).

${ }^{45}$ Kritisk er også Jo Hov. Se særlig Hov 2017, s. 418: «det er ikke gitt at alle de løsninger som er tatt med i denne katalogen, egentlig fortjener å bli ansett som uttrykk for gjeldende rett. For å si det rett ut: Oppregningen i tvistelovens forarbeider er etter min oppfatning både firkantet og ureflektert.»

${ }^{46}$ NOU 2001: 32A, s. 383 (eksempel B).

${ }^{47}$ Skoghøy hevder at utvalgets oppfatning er uttrykk for sikker rett, og begrunner det med henvisning til den rettslige tradisjon, se Skoghøy 2017, s. 1090. Se også Robberstad 2006, s. 173-174. Kritisk til tradisjonens overleveringer, slik som denne, er Hov 2010 s. 1242 og 1250; Hov 2017 s. 418 og 423-424. Uansett om oppfatningen har støtte i tradisjon, eller bare opinion: Den synes moden for revisjon.

${ }^{48}$ NOU 2001: 32A, s. 383 (eksempel A).
} 
at beregningsreglene er forskjellige $»{ }^{49}$ Dette gir inntrykk av at $\mathrm{H} \varnothing$ yesterett fremhevet rettsfølgene som et utgangspunkt for vurderingen. Men at disse [«kravene»] er kvalitativt ulike, nevnes kun en passant, ${ }^{50}$ og når Høyesterett konkluderer, er det de ulike rettsvilkårene som fremheves:

«Forskjellen i vilkårene for et erstatningskrav, henholdsvis krav om prisavslag, og forskjellen i utmålingen av kravene, må etter min mening tillegges avgjørende vekt ved vurderingen av om en står overfor samme krav i relasjon til tvistemålsloven § 366. ${ }^{51}$

Det er også ett av eksemplene i forarbeidene som utvalget selv erkjente at det hadde vanskelig for å forlike med sin egen forståelse. Utvalget konstaterer at ugyldighet og erstatningsansvar $i$ utgangspunktet er ulike rettsforhold, og at dette iallfall må gjelde der en første dom går ut på ugyldighet, fordi ugyldighet aldri er en tilstrekkelig betingelse for erstatningsansvar. Så følger det interessante: Hva om dommen i den første saken konkluderer med at en avtale eller et vedtak er gyldig. Kan saks $\varnothing$ ker da reise ny sak med krav om erstatning, utelukkende begrunnet med at avtalen eller vedtaket allikevel er ugyldig?

Høyesterett hadde tatt stilling til en lignende problemstilling i Rt. 1993 s. 1606. Etter at saksøker ikke hadde fått medhold $\mathrm{i}$ at det forelå en ugyldig endringsoppsigelse, med den begrunnelse at det ikke forelå noen oppsigelse, reiste hun ny sak med krav om erstatning begrunnet med at hun var ugyldig oppsagt. Retten la til grunn at et slikt krav ikke kan fremmes. Slik flertallet formulerte det, var dette «en konsekvens av at det er rettskraftig avgjort at det ikke foreligger noen oppsigelse». ${ }^{52}$

En tilsvarende forståelse får tilslutning av Tvistemålsutvalget:

«Hvis det i sak én omvendt blir lagt til grunn at avtalen eller vedtaket er gyldig, vil nok en ny sak med krav om erstatning utelukkende begrunnet med at avtalen likevel er ugyldig, bli avvist fordi spørsmålet anses rettskraftig avgjort. Det kan for eksempel vises til kjennelsen i Rt. 1993 s. 1606. 1 $^{53}$

Som utvalget skriver, lar forståelsen «seg vanskelig forene» med utvalgets generelle regel, ${ }^{54}$ hvilket tvinger det til å konstruere sin variant av de klassiske episykler:

"Utvalget mener at resultatet kan forklares ut fra en særregel om avledet objektiv rettskraft, men dette er unektelig nokså komplisert. [...] $\|^{55}$

Etter mitt syn hadde ikke dette trengt å være komplisert. Det krever bare en erkjennelse av at det er viktigere om rettsvilkårene er sammenfallende, enn om rettsfølgene er ulike. Her er en nødvendig forutsetning for begge kravene at vilkårene om ugyldighet er oppfylt, og i den første saken er det rettskraftig avgjort at de ikke er det. Det alene bør anses avgjørende. Da blir det hele elementært.

Også på bakgrunn av gjeldende rett og utvalgets egne eksempler synes altså oppfatningen om rettsfølgenes betydning vanskelig å forsvare. Samtidig synes den ikke vanskelig å forklare. Den harmonerer godt med dagligspråkets bruk av ordet «krav»: Krever man ulike ting, står vi overfor ulike

\footnotetext{
49 Ibid., s. 384-385 (min utheving).

${ }^{50}$ Rt. 2000 s. 199 , på s. 203.

${ }^{51}$ Ibid., s. 204. Kritisk til avgjørelsen er Hov 2010, s. 1243; bifallende er Skoghøy 2017, s. 1075 og 1082.

52 Rt. 1993 s. 1606 , på s. 1608.

${ }^{53}$ NOU 2001: 32A, s. 384; jf. også Ot.prp. nr. 51 (2004-2005), s. 441.

54 NOU 2001: 32A, s. 384.

55 Ibid.
} 
krav. Oppfatningen fungerer derfor utmerket som en tommelfingerregel når vi spør om to krav er like eller ulike. Men det er ikke dette spørsmålet man bør stille.

I analysen av rettskraftens såkalte identitetsproblem - spørsmålet om to krav, A og B, er samme Krav - kan vi skille ut de trivielle tilfellene. Dette er tilfeller hvor A og B på alle relevante måter er like. Vi kan for eksempel tenke oss at saksøker etter ikke å ha fått medhold i sitt krav om erstatning, reiser ny sak med et helt identisk krav om erstatning. Slike tilfeller har en opplagt løsning, og vi kan legge disse til side. De tilfellene vi da står igjen med, er de hvor A og B er ulike. Spørsmålet vi bør stille, er således ikke hva som tilsier at to krav er like eller ulike, men hva som kan begrunne at to ulike krav skal anses identiske. - Hva skal til for at de, til tross for sine ulikheter, må anses som det samme Kravet? Først når vi stiller dette spørsmålet, har vi kommet til problemets kjerne.

Når vi stiller mer presise spørsmål, vil flere lærdommer åpenbare seg. For det første mener jeg det da blir klart at kjennetegn ved rettsfølgene normalt må anses å være av underordnet betydning. Hvis $\mathrm{A}$ og B har distinkte rettsvilkår eller knytter an til forskjellige saksforhold, bør det i utgangspunktet være tilstrekkelig til å konstatere at vi står overfor ulike Krav; at rettsfølgene ikke er ulike, utgjør ingen relevant forskjell. Og hvis A og B har identiske rettsvilkår og knytter an til det samme saksforholdet, og det i den første saken er rettskraftig avgjort at vilkårene ikke er oppfylt, bør det ikke tilkjennes noen betydning at B har en annen rettsfølge enn A. I tilfeller hvor A og B kun har delvis overlappende rettsvilkår, eller hvor det er en annen type svakere sammenheng mellom kravene, kan Iøsningen være mer tvilsom. Da bør man spørre hvilken betydning disse likhetene eller sammenhengene bør tilkjennes på bakgrunn av rettskraftregelens formål og bakenforliggende hensyn. Også her vil det imidlertid normalt være mer relevant å se på likheter eller sammenhenger mellom faktiske og rettslige vurderingstemaer enn på om rettsfølgene er like eller ulike.

Forståelsen i forarbeidene springer ut av det som er en klassisk feilkilde i all vitenskap: en forveksling av korrelasjon og forklaringskraft. Det er høy korrelasjon - samvariasjon - mellom ulike krav og ulike rettsfølger. Men det betyr ikke at (u)like rettsfølger er egnet til å forklare, eller å begrunne, hvorfor to ulike krav skal anses som det samme Kravet. En slik forveksling kan i praksis medføre at forhold uten normativ betydning tillegges en vekt i konkrete vurderinger som det ikke er grunnlag for, eller at vurderingene blir konsentrert om uvesentlige forhold $\mathrm{i}$ stedet for reelle problemer.

Forløperen Rt. 2012 s. 1138, som jeg var inne på over, gir én illustrasjon. I en første sak var saksøker tilkjent erstatning for råteskader i takkonstruksjonen på en eiendom som følge av lekkasjer. Under utbedringen av skadene ble det oppdaget nye og mer omfattende råteskader, og hun reiste derfor ny sak, denne gang med krav om prisavslag, for også å få dekket de nyoppdagede tapspostene. Saken reiste to spørsmål: For det første om et (hypotetisk) krav om erstatning for de nye postene ville måtte avvises fordi de ulike tapspostene hørte til det samme Kravet. Og, hvis dette ble besvart bekreftende, om retten til prisavslag allikevel var i behold fordi krav om prisavslag og erstatning er forskjellige Krav.

Størstedelen av Høyesteretts vurdering er viet det «klassiske» spørsmålet om krav om prisavslag og erstatning er forskjellige Krav, hvilket ble besvart benektende. Etter mitt skjønn er dette, i denne sammenheng, et uinteressant spørsmål; har man allerede fått erstatning for mangelen, kan man ikke kreve prisavslag. ${ }^{56}$ Det første spørsmålet er klart mest interessant: Hvis det i etterkant av en første sak viser seg at en skade er mer omfattende enn antatt, kan man da kreve tapsdifferansen dekket? Gjelder dette i så fall kun der man ikke har kunnskap om hele skadeomfanget? Eller gjelder det kanskje et krav om aktsom god tro? Og hvis man ikke kan kreve tapsdifferansen dekket, hvordan skal man skille mellom de tapspostene som hører til det samme Kravet, og tapsposter som hører til et annet? Mer prinsipielt reiser dette spørsmål om Kravets metafysikk, og om det har en virkelighetstilknytning som kan avgrenses i tid og rom.

\footnotetext{
${ }^{56}$ For en liknende kritikk av den andre forløperen, Rt. 2009 s. 286, se Hov 2017, s. 420-421.
} 
Slike spørsmål drøftes ikke av Høyesterett. Som jeg redegjorde for i punktet over, forankret $\mathrm{H} \varnothing$ yesterett sin vurdering av det første spørsmålet i Rt. 2006 s. 983, som gjaldt et spørsmål om foreldelse. Som en begrunnelse for at det konkrete kravet ville måtte avvises, anså retten følgende konstatering tilstrekkelig (avsnitt 21): «[...] Antonsens krav i saken i 2010 var begrunnet i råteskader med utgangspunkt i takkonstruksjoner. I stevningen i foreliggende sak knyttes kravet opp mot 'mer omfattende råteskader', men disse synes fortsatt å ha sitt utspring i takkonstruksjonene.» Det er på ingen måte opplagt at Kravets metafysikk har en virkelighetstilknytning til noe så prosaisk som takkonstruksjoner. ${ }^{57}$

Fordi ulike rettsvilkår bare er et korrelerende kjennetegn, er det også lite instruktivt når disse presenteres som «momenter» i en avveining («totalbedømmelse»). Det gir liten mening å avveie graden av (u)likhet mot andre forhold, for slike kjennetegn - herunder kjennetegn ved rettsvilkårene til to krav - har i seg selv ingen normativ betydning. Den betydning de måtte ha, beror på rettskraftregelens formål og bakenforliggende hensyn, som vi må se hen til for å vurdere hvilke kjennetegn som bør anses mer eller mindre betydningsfulle i det konkrete tilfellet. Påpekningen av relevante likheter og sammenhenger mellom to ulike krav bør derfor ikke forstås som en oppstilling av momenter til en avveining. Det dreier seg utelukkende om å stille de rette spørsmål til den vurdering som skal foretas.

I HR-2018-1130-A (avsnitt 31) skriver Høyesterett at «Rettsfølgjene av prisavslag og skadebot som kontraktsbrotssanksjonar er kvalitativt like. [...] Det er vidare god prosessøkonomi å handsame desse krava samla. [...]» Uttalelsen kan gi inntrykk av at likheten mellom rettsfølgene anses som ett moment, og at prosessøkonomiske hensyn anses som et annet moment, i en avveining. I den grad likheten mellom rettsfølgene var relevant for vurderingen, kunne man imidlertid tenke seg at det var god prosess $\varnothing$ konomi å behandle kravene samlet fordi rettsfølgene var like; slike kjennetegn har ingen betydning ved siden av, eller i tillegg til, de hensyn rettskraftregelen bygger på.

Som nevnt er den forståelse som fremkommer i forarbeidene, et uttrykk for gjengse oppfatninger i norsk juridisk teori. Dette er derfor ikke bare en svakhet ved forarbeidene, men en svakhet som hefter ved utbredte oppfatninger i teorien, og ved den tilnærming til rettskraftens teoretiske utfordringer som har vært lagt til grunn i norsk rettsvitenskap. Utforskningen av rettskraftens identitetsproblem har ikke vært ledsaget av tilstrekkelig metateoretisk refleksjon - det vil si refleksjon om hvordan man bør nærme seg et slikt teoretisk problem som rettskraften utgjør. ${ }^{58}$ Resultatet er teoretiske utlegninger som er strukturert rundt ulike korrelerende kjennetegn, til fortrengsel for en forståelse som søker en begrunnelse eller forklaring; det er som en redegjørelse for fremtredende kjennetegn ved de ulike stenene i en mosaikk, som er blind for det mønster de inngår $\mathrm{i}$.

Vi kan komme nærmere en bedre forståelse av dette problemkomplekset om vi i stedet spør hva som kan begrunne at to ulike krav bør anses identiske i relasjon til rettskraftens avvisningsregel. ${ }^{59}$

\footnotetext{
${ }^{57}$ Sml. Hov 2017, s. 421.

${ }^{58}$ Med dette mener jeg ikke å si at slik refleksjon har vært helt fraværende (se f.eks. Robberstad 2006, s. 175), kun at det finnes uløste problemer som ikke kan løses uten slik refleksjon. Kritisk til den norske rettsvitenskapelige innstillingen er også Robberstad 2006, s. 7n.

${ }^{59}$ Dette er også kalt rettskraftens negative virkning. Den positive rettskraftvirkningen, jf. tvisteloven § 19-15

(2), dreier seg om hva retten skal legge til grunn uten realitetsprøving i en ny sak. Det er en opplagt sammenheng mellom virkningene, og de spørsmål som den positive virkningen reiser, må normalt løses på samme måte som for den negative. Men som Eckhoff skriver, bør man være oppmerksom på at løsningen her kan bli en annen, se Eckhoff 1945, s. 18. Robberstad 2006, s. 51, hevder at det ikke er grunn til å ta noen slik reservasjon fordi «[k]ravets identitet kan rent logisk ikke være forskjellig i de to relasjonene». Et slikt argument mister enhver overbevisningskraft når man innser at spørsmålet om rettskraftens negative virkning slettes ikke dreier seg om identitet, men om grunner til at to ulike krav skal anses identiske. Spørsmålet om den positive
} 
Problemstillingen dreier seg altså i sin kjerne om når et tidligere avgjort krav skal sperre for et annet, til tross for at de to ikke er samme krav. Eller, med andre ord, når skal saksøker tape retten til å fremme et krav på grunn av en tidligere avgjørelse om et annet? Når vi stiller slike enklere og mer presise spørsmål, kan vi se at problemstillingen vil kunne oppstå i forskjellige typer av situasjoner, og at det til disse vil være ulike begrunnelser som frembyr seg.

Som et eksempel på et første typetilfelle kan vi forestille oss at saksøker har fått medhold i sitt krav om prisavslag for en mangel. Han reiser så ny sak med krav om erstatning for den samme mangelen. Jeg legger til grunn at saken må avvises..$^{60}$ Men hvorfor? En påpekning av at rettsfølgene er relativt like, eller at rettsvilkårene er det samme, gir ingen tilfredsstillende begrunnelse. Her er det mer nærliggende å peke på en materiellrettslig forbindelse mellom reglene: Prisavslag og erstatning er alternative, gjensidig utelukkende beføyelser, forbundet gjennom grunnvilkåret om mangel. Så bordet fanger; når man får tilkjent den ene, utslukkes retten til å kreve (også) den andre. La oss kalle dette ekstingverende rettskraft.

Rt. 1982 s. 1093 gir et eksempel. En arbeidstaker hadde fått tilkjent erstatning for ikke- økonomisk skade etter en ugyldig avskjedigelse, og reiste senere sak med krav om lønn og feriepenger samt renter for tiden mellom avskjedigelsen og domstidspunktet. Kjæremålsutvalget fant at saken måtte avvises. Kravet om erstatning var etter dagjeldende arbeidsmiljølov $\S 66 \mathrm{nr}$. 5 fastsatt til «det beløp som retten under hensyn til det $\varnothing$ konomiske tap, arbeidsgiverens og arbeidstakerens forhold og omstendighetene for $\varnothing$ vrig finner rimelig». Erstatningskravet måtte dermed forstås slik at det innbefattet krav om lønn, og det var således ikke adgang til å fremme et separat lønnskrav i en senere sak.

Et eksempel på et annet typetilfelle er det første scenarioet jeg skisserte i punkt 2 over: I en første sak får kjøper ikke medhold i sitt krav om erstatning, med den begrunnelse at det ikke foreligger en mangel. Han reiser så ny sak med krav om prisavslag for den samme påståtte mangelen. Om vi mener at dette kravet bør avvises, trenger vi en annen begrunnelse enn ved ekstingverende rettskraft. Her synes det nærliggende å vise til klassiske betraktninger om at man ikke bør ha rett til å få vurdert det samme forhold to ganger (ne bis in idem). Når det i en første sak er rettskraftig fastslått at nødvendige betingelser for det andre kravet ikke er oppfylt, kan vi avlede rettskraftvirkningen fra den første saken til også å gjelde det andre kravet. Vi kan kalle dette avledet rettskraft.

Et eksempel er Rt. 1993 s. 1606. Saksøker hadde i en første sak ikke fått medhold i at det forelå en ugyldig endringsoppsigelse, med den begrunnelse at det ikke forelå noen oppsigelse. Hun ble så nektet å fremme ny sak med krav om erstatning begrunnet med at hun var ugyldig oppsagt. Slik flertallet formulerte det (s. 1608) var dette «en konsekvens av at det er rettskraftig avgjort at det ikke foreligger noen oppsigelse».

Det andre scenarioet jeg skisserte i punkt 2, gir et eksempel på et tredje typetilfelle: Etter at kjøper ikke fikk medhold $i$ sitt krav om erstatning i den første saken, med den begrunnelse at han ikke hadde lidd et $\varnothing$ konomisk tap, reiser han ny sak med krav om prisavslag, som han skulle fått medhold i om kravet var fremmet i den første saken. Min oppfatning var som nevnt at dette andre kravet bør tillates fremmet. Her er jeg bare opptatt av hvordan vi kan begrunne at det eventuelt ikke skal tillates fremmet. I kontrast til det som gjelder ved ekstingverende og avledet rettskraft, kan vi ikke begrunne

virkning dreier seg dessuten ikke om identitet overhodet, men om når en første avgjørelse skal legges til grunn uten realitetsprøving ved avgjørelsen av et annet krav.

${ }^{60} \mathrm{Hov}$ anfører om et liknende eksempel (omlevering/prisavslag) at saken må fremmes, men at dommen i den første saken må lede til frifinnelse av saksøkte i den andre, se Hov 2010, s. 1244-1245; Hov 2017, s. 419. Mitt inntrykk er at Hov på dette punktet har et mer formalistisk syn enn Høyesterett og forfattere som Skoghøy og Robberstad, som, muligens av pragmatiske grunner, er mindre forbeholdne i synet på når en sak bør avvises. Mitt formål her er uansett bare å få frem forskjellige begrunnelser for hvorfor to ulike krav bør anses identiske. 
dette med henvisning til hva som er avgjort i den første saken. Vi må i så fall begrunne det med at det andre kravet burde vært avgjort i den første saken, og at den første saken derfor bør prekludere behandling av det andre kravet i en ny sak. La oss kalle dette prekluderende rettskraft.

Vi kan avgrense dette typetilfellet, som også involverer to ulike rettslige grunnlag, mot ekstingverende og avledet rettskraft, på en slik måte at vi inkluderer to ulike situasjoner som deler vesentlige likhetstrekk. En første situasjon står vi overfor hvor saksøker etter å ha fått medhold i et krav i den første saken, reiser ny sak om et annet krav som, kan vi anta, har en forbindelse til det første kravet, men hvor forbindelsen ikke er slik at de to kravene er gjensidig utelukkende. En annen situasjon er den hvor saksøker etter ikke å ha fått medhold i et krav i den første saken, reiser en ny sak om et annet krav som, kan vi anta, har en forbindelse til det første, men hvor avgjørelsen av det første ikke gir oss sikre holdepunkter for at det andre ikke ville ført frem, om det var fremmet i den første saken. I begge situasjoner kan det være tvilsomt, eller helt åpent, om det andre kravet er holdbart, men problemstillingen, og det potensielt urimelige ved å akseptere prekluderende rettskraft, blir satt på spissen om vi forutsetter at det er klart at det andre kravet ville ført frem. Så vi kan spørre: I hvilke situasjoner bør vi akseptere at et (potensielt) rettmessig krav går tapt utelukkende fordi det ikke ble reist i en sak hvor et relatert krav basert på et annet rettsgrunnlag ble behandlet?

En regel om prekluderende rettskraft gjelder for krav om sakskostnader. Se for eksempel ankeutvalgets uttalelse i Rt. 2015 s. 897 avsnitt 11: «Etter praksis er sakskostnadskravet for ein instans tapt dersom det ikkje blir sett fram før saka er avslutta i vedkomande instans, jf. HR-2011-678-U og Rt-2008-952.» Jeg oppfatter dette som en særregel. Argumenter om hva som bør behandles samlet, har riktignok en viss utbredelse i rettspraksis - og kanskje særlig i andre relasjoner - men jeg kjenner ikke til andre tilfeller hvor et krav har blitt avvist som rettskraftig avgjort utelukkende med den begrunnelse at det burde ha blitt behandlet i en annen sak. Som Robberstad med rette påpeker, finnes det derimot mange avgjørelser hvor et slikt argument var tilgjengelig, men ikke ble anvendt. ${ }^{61}$

For fullstendighets skyld kan vi også ta med et fjerde typetilfelle. Et eksempel på dette vil være at saksøker etter å ha fått medhold i sitt krav om erstatning for en mangel, oppdager mer omfattende skader, og reiser ny sak med krav om å få dekket tapsdifferansen. I likhet med det som er tilfellet ved prekluderende rettskraft, er det nærliggende å begrunne en eventuell avvisning av et slikt krav med at det burde vært avgjort i den første saken, og at rettskraftvirkningen til det første kravet derfor må gjelde for et utvidet saksforhold. Vi kan kalle dette utvidet rettskraft. ${ }^{62}$

I kontrast til de tre $\varnothing v$ rige typetilfellene, som involverte to ulike rettslige grunnlag, dreier dette typetilfellet seg om ulike, men, kan vi anta, relaterte saksforhold. Fordi ulike rettslige grunnlag ofte vil knytte an til ulike (sider av samme) saksforhold, kan det være tilfeller som det er uklart hvordan vi bør kategorisere (uten at det bør ha særlig betydning). Det potensielt urimelige ved å akseptere utvidet rettskraft blir satt på spissen om vi forutsetter at saksøker også ville fått medhold i det nye kravet om dette var fremmet i den første saken, og at saks $\varnothing$ ker ikke hadde noen reell mulighet til å fremme kravene samlet. Men ved utforskningen av dette typetilfellet trenger vi ikke å forutsette noen av delene. Vi kan også inkludere tilfeller hvor saksøker ikke fikk medhold i den første saken, og så reiser ny sak om et relatert saksforhold (mange av disse vil også være mulige tilfeller av avledet rettskraft), og tilfeller hvor saksøker hadde mulighet til å fremme kravene samlet. Alt vi forutsetter, er at det er en sammenheng mellom saksforholdene. Så kan vi spørre: I hvilke situasjoner bør vi

\footnotetext{
${ }^{61}$ Se kritikken av et slikt argument i Robberstad 2006, s. 164-165.

${ }^{62}$ Termene «avledet» og «utvidet» har i teorien blitt brukt primært i tilknytning til rettskraftens såkalte subjektive side, som dreier seg om hvem som anses bundet av rettskraften. Se f.eks. Schei mfl. 2013, s. 668669. Jeg knytter de her til rettskraftens såkalte objektive side.
} 
akseptere at et (potensielt) rettmessig krav går tapt utelukkende fordi det ikke har blitt reist i en sak hvor et annet krav om et relatert saksforhold ble behandlet?

Et mulig eksempel er ovennevnte Rt. 2012 s. 1138. Etter at saks $\varnothing$ ker fikk tilkjent erstatning for råteskader $\mathrm{i}$ takkonstruksjonen på en eiendom som følge av lekkasjer, reiste hun ny sak om «mer omfattende råteskader», men kravet ble avvist fordi «disse synes fortsatt å ha sitt utspring i takkonstruksjonene» (avsnitt 21). Jeg oppfatter avgjørelsen som et avvik. Normalt har Høyesterett vurdert om saksforholdet i den første saken lar seg individualisere, se f.eks. Rt. 2013 s. 434 avsnitt 21-23 (om litispendens). Det spesielle med kjennelsen fra 2012 var at Høyesterett ikke en gang gjorde et fors $\varnothing k$ på slik individualisering. ${ }^{63}$

Tre av disse fire typetilfellene - ekstingverende, avledet og prekluderende rettskraft - involverer altså to ulike rettslige grunnlag. Og fordi disse typetilfellene aktualiserer forskjellige begrunnelser, som i hvert fall til dels er gjensidig uavhengige, kan vi ikke trekke slutninger om at to ulike krav bør anses identiske i ett typetilfelle, utelukkende basert på hva som gjelder i et annet. (Legg dessuten merke til hvor misvisende det i alle typetilfellene er å snakke om hva som utgjør «samme/identiske krav».)

Vi kan videre se at det kan være gode grunner for å anse to ulike krav som identiske i ett typetilfelle, men ikke i et annet. Gode grunner taler for at en avgjørelse av et krav om ugyldighet som konkluderer med at et vedtak eller annet er gyldig, bør sperre for et senere krav om erstatning for ugyldighet, men krav om ugyldighet og erstatning for ugyldighet er opplagt ikke gjensidig utelukkende, og det kan virke urimelig om en avgjørelse om at et vedtak er ugyldig, skal sperre for et senere krav om erstatning basert på ugyldighet. Vi kan således ha avledet rettskraft, uten ekstingverende eller prekluderende rettskraft. Det kan også argumenteres for at vi for eksempel for krav om erstatning og prisavslag, eller for krav om erstatning basert på ulike ansvarsgrunnlag, bør tillate ekstingverende og avledet rettskraft, men ikke prekluderende rettskraft.

Dette forteller oss at vi ikke kan konstruere en tilfredsstillende lære om kravets «identitet» som tar utgangspunkt i ulike typer av krav og stiller spørsmål om disse er «samme krav». For dette vil kunne resultere i generelle svar som kan være godt tilpasset ett typetilfelle, men som ikke passer for et annet. Det vil skape disharmoni. Og fordi det kan være tilfeldig hvilket typetilfelle som kommer for retten, vil løsningen kunne bli vilkårlig. Og hvis et annet typetilfelle kommer for retten, som Iøsningen er svakt tilpasset, kan den bli så ustabil at den blir satt til side, til fordel for en ny forståelse, som vil kunne være like vilkårlig og ustabil.

Dette er imidlertid Tvistemålsutvalgets forutsetning: Grensen mellom ulike krav må «trekkes mellom typer av krav etter generelle kriterier». ${ }^{64}$ En slik forutsetning synes også å ligge til grunn for selve tenkemåten i norsk juridisk teori, og den farger av på de spørsmål som stilles: Man tar utgangspunkt i ulike typer av krav og spør om disse er samme eller forskjellige krav. Resultatet: vilkårlighet, disharmoni og en ustabil rettsorden.

Tvistemålsutvalget skriver: «Det kan reises spørsmål om totalbedømmelsen [av om man står overfor forskjellige krav] skal skje konkret, med forankring i den påstand og argumentasjon parten gjør gjeldende i den enkelte sak, eller om grensen skal trekkes mellom typer av krav etter generelle kriterier. I Høyesteretts dom i Rt. 2000 side 199, hvor flertallet kom til at krav om erstatning og prisavslag for mangler etter lov om avhending av fast eiendom må anses som forskjellige krav, ble det uttalt at det må gjelde generelt, uansett om saks økeren i den enkelte sak krever dekket de samme tapsposter med de samme argumenter.. ${ }^{65}$

\footnotetext{
${ }^{63}$ Se også Skoghøy 1995, s. 33.

64 NOU 2001: 32A, s. 383.

65 Ibid.
} 
Det er uklart hvordan utvalget ser for seg at en grensedragning kan skje «mellom typer av krav etter generelle kriterier», samtidig som det skal foretas en «totalbedømmelse». Det er også uklart hvordan uttalelsen innledningsvis i dette punktet, om en totalbedømmelse, lar seg forene med utvalgets eget eksempelmateriale, som synes å forutsette generelle grensedragninger mellom ulike typer av krav. Uansett er slutningen fra Pelsdyrhall svak. Dommens uttalelse om «forholdene i den enkelte sak» siktet, slik jeg forstår den, spesifikt til størrelsen på og det faktiske grunnlaget for de respektive kravene; «at den $\varnothing$ konomiske rammen for kjøperens krav i vår sak er den samme», kunne ikke være avgjørende. ${ }^{66}$ Den gjaldt altså kun ett konkret forhold, som ikke kunne tilkjennes avgjørende betydning, og den gir ingen støtte for at grensedragningen må skje «mellom typer av krav etter generelle kriterier».

At det ikke lar seg gjøre å gi en tilfredsstillende lære som trekker opp grensen mellom typer av krav, innebærer imidlertid $i k k e$ at det er umulig å gi en generell løsning på problemet. For det er mulig å si noe generelt om ekstingverende, avledet, prekluderende og utvidet rettskraft.

Mitt syn: Ekstingverende rettskraft er en direkte konsekvens av at noen beføyelser er alternative og gjensidig utelukkende, og bør være ukontroversielt (og ekstingverte krav bør avvises). Avledet rettskraft hviler på en sunn begrunnelse. Det bør utelukkende tillates i klare tilfeller, hvor avgjørelsen i den første saken ikke etterlater tvil om at nødvendige betingelser for det andre kravet ikke var ansett oppfylt. Motstridende hensyn kan antagelig begrunne visse unntak; hvilke lar jeg stå åpent. Prekluderende rettskraft bør, med unntak for faste og transparente særregler, aldri tillates. Lovens formulering foreskriver avvisning av krav som er rettskraftig avgjort, ikke krav som burde vært rettskraftig avgjort, og reelle hensyn støtter etter mitt syn også opp om en slik forståelse. ${ }^{67}$ Utvidet rettskraft rammes av de samme innvendinger som prekluderende rettskraft, og bør aldri tillates. ${ }^{68}$ Uklarhet om den første avgjørelsens bindende virkning (som man riktignok kan kreve fastlagt ved ny dom, jf. tvisteloven § 19-15 (3) forutsetningsvis), må i en ny sak løses til fordel for saksøkte.

Dette lar oss enn videre se at dette er et problem som ligger under vår kontroll. Med dette sikter jeg ikke bare til at vi kan løse problemet, men at det er opp til oss som et rettssamfunn å bestemme problemets vanskelighetsgrad. Å tillate prekluderende og/eller utvidet rettskraft vil åpne slusene for ad hoc synsing fra domstolene om hva som allerede burde vært avgjort. Fordi det er vanskelig å gi gode, generelle regler som åpner for dette, vil en slik regelforståelse virke prosessdrivende. Hvis vi derimot setter en strek over prekluderende og utvidet rettskraft, blir problemet med ett både mindre komplekst og langt mindre komplisert. Høyesterett kan oppnå dette med et pennestrøk. Vi vil da stå igjen med en enkel regel som, foruten å foreskrive avvisning av et nytt identisk krav og nye krav som angriper forutsetningene til det første kravet (med forbehold for visse prejudisielle forhold), utelukkende får anvendelse i visse tilfeller av ekstingverende og avledet rettskraft. ${ }^{69}$

\section{Abstraksjon og sunn juridisk fornuft}

Kun noen måneder før kjennelsen i HR-2018-1130-A avsa Høyesterett dom i en annen sak, som det er interessant å sammenligne med. Også i HR-2018-383-A var det spørsmål om en forbruker hadde tapt sitt krav overfor en entreprenør. Her la Høyesterett til grunn at det var et skille mellom forbrukerens innvendinger mot entreprenørens sluttoppgjør, som typisk kunne gå ut på «at entreprenøren ikke har grunnlag for det vederlaget han har krevd», og forbrukerens egne misligholdskrav mot entreprenøren, som kan fremsettes som en innvending mot vederlaget, men

\footnotetext{
${ }^{66}$ Rt. 2000 s. 199, på s. 203-204.

${ }^{67}$ Se punkt 2 over, avslutningsvis.

${ }^{68}$ I samme retning (om prekluderende og utvidet rettskraft) Robberstad 2006, s. 164-165. Se også Eckhoff 1945 , s. 84-86.

69 Problemet om rettskraftens negative virkning har også noen andre sider, som jeg ikke har tatt opp her, slik som diskusjonen rundt facta supervenientes; heller ikke her kan jeg se at det ligger særlig dype utfordringer.
} 
som også kan fremsettes særskilt. Og Høyesterett konkluderte med at «det bare er forbrukerens innvendinger som tapes, ikke hans krav» (avsnitt 35).

Saken i HR-2018-383-A gjaldt ikke et krav om prisavslag eller erstatning, men et krav på dagmulkt. Og den dreide seg ikke om rettskraft, men om hvorvidt forbrukeren hadde tapt sitt krav fordi han hadde betalt entreprenørens regning uten å protestere mot sluttoppgjøret. Dommen var derfor ikke et direkte anvendelig prejudikat ved avgjørelsen av saken i HR-2018-1130-A. Det interessante i denne sammenheng er imidlertid at $\mathrm{H} \varnothing$ yesterett, fordi saken ikke gjaldt et spørsmål om rettskraft, heller ikke baserte sin vurdering på en abstrakt lære om hva som utgjør samme Krav. I stedet foretok Høyesterett en alminnelig tolkning av blant annet håndverkertjenesteloven $\S 48$ tredje ledd, og konkluderte fornuftig nok med at det var et skille mellom innsigelser mot vederlaget og forbrukerens misligholdskrav. Slik mener jeg Høyesterett også burde ha konkludert i HR-2018-1130-A. Men her landet retten altså på at krav om prisavslag er samme Krav som et krav på vederlag. Konsekvensen kan se ut til å være at en forbruker ikke vil tape sitt krav mot entreprenøren ved å betale dennes regning (det «mer»), men vil tape det om han får dom på betaling mot seg (det «mindre»). Det fremstår for meg som en lite harmonisk rettstilstand.

Etter mitt syn er det imidlertid liten grunn til å tilkjenne HR-2018-1130-A noen prejudikatverdi; den bør i hvert fall ikke anses som et prejudikat av $\mathrm{H} \varnothing$ yesterett selv. Dette skyldes ikke svakheter ved argumentasjonen i avgjørelsen; i første rekke skyldes det svakheter ved de premisser den bygger på.

Nyere norsk rettsvitenskap har lagt til grunn et paradigme som forutsetter at to ulike krav - slik som krav om prisavslag og krav om erstatning - enten er, eller ikke er, det samme Kravet i alle tenkelige relasjoner. Fordi ordet «krav» spiller en sentral rolle i bestemmelser som bygger på til dels ulike hensyn, og fordi det finnes forskjellige grunner til at to krav bør anses identiske i ulike relasjoner, vil et slikt paradigme uvegerlig lede til disharmoni og vilkårlige og ustabile løsninger. Jakten på slike generelle svar kan aldri bli annet enn et sisyfosarbeid, for, som Eckhoff så tydelig så, «synes [det] klart at de spørsmål som reiser seg til dels må løses forskjellig». ${ }^{70}$

Problemet med paradigmet er ikke bare at det er utjenlig. For en sunn juridisk fornuft er det imperativt at de ulikeartede hensyn bestemmelsene er uttrykk for, samt de ulike grunner for at to krav bør anses identiske, tillegges tilbørlig vekt i rettsanvendelsen. Det kan ikke oppnås så lenge man insisterer på at bestemmelsenes sentrale begrep skal forstås på en måte som er blind for de nyanser som måtte følge av de selvsamme hensyn og grunner. Paradigmet er ikke forenelig med sunn juridisk fornuft; fornuften krever at det forkastes.

Høyesterett kan lede an i utviklingen mot en mer nyansert forståelse ved å anlegge en mer kritisk tolkningsstil - som ser forbi uttalelser om forståelsen av ordet «krav» i andre relasjoner, til de bakenforliggende realiteter - samt ved å gi en generell tolkningsuttalelse som rehabiliterer den tidligere oppfatning i Høyesterett fra Rt. 1997 s. 1477, og som ble bekreftet i Pelsdyrhall: «at de hensyn som har ført til den aktuelle lovregel der dette med nye krav har betydning, vil være et sentralt tolkingsmoment». ${ }^{71} \mathrm{H} \varnothing$ yesterett kan også bidra til en avklaring av tolkningen av tvisteloven $\S$ 19-15 (3) ved å gi generelle uttalelser om ekstingverende, avledet, prekluderende og utvidet rettskraft.

Ansvaret for en slik utvikling kan imidlertid ikke falle på Høyesterett alene. I juridisk teori og praksis har kravbegrepets ulike tråder blitt filtret sammen. Å nøste opp denne floken bør være en oppgave for rettsvitenskapen. Det er behov for en systematisk og kritisk kartlegging av hvilke nyanser som har

\footnotetext{
${ }^{70}$ Eckhoff 1945, s. 59.

${ }^{71}$ Rt. 2000 s. 199, på s. 203.
} 
vært til stede i tidligere rettspraksis. Og denne bør ledsages av en analytisk og prinsipiell vurdering av hvilke sammenhenger og forskjeller det bør være i forståelsen av hva som i ulike relasjoner skal anses som samme Krav.

Dette bør ikke være en uoverkommelig oppgave. Problemet ved identitetsproblemet er at diskusjonen har vært løftet opp på et så abstrakt nivå at den har generert sine egne problemer, tvilsomme oppfatninger og tåkete argumentasjon. ${ }^{72} \mathrm{~N} \varnothing \mathrm{kkelen}$ til en endelig løsning ligger $\mathrm{i}$ å bringe diskusjonen ned på virkelighetsplanet, hvilket peker i retning av dypere spørsmål: ${ }^{73} \mathrm{Hva}$ skal vi gjøre med Kravet? Bør vi fors $\varnothing$ ke å reformulere loven kun med referanse til virkeligheten? Er det mulig å lykkes i et slikt forsett?

72 Eckhoff så også det uheldige ved diskusjonens abstrakte karakter, se Eckhoff 1945, s. 144-145.

${ }^{73}$ Se punkt 3 over, avslutningsvis; Fuller 1930-1931, s. 366. 